\title{
Real Interest Rate Persistence: Evidence and Implications
}

\author{
Christopher J. Neely and David E. Rapach
}

\begin{abstract}
The real interest rate plays a central role in many important financial and macroeconomic models, including the consumption-based asset pricing model, neoclassical growth model, and models of the monetary transmission mechanism. The authors selectively survey the empirical literature that examines the time-series properties of real interest rates. A key stylized fact is that postwar real interest rates exhibit substantial persistence, shown by extended periods when the real interest rate is substantially above or below the sample mean. The finding of persistence in real interest rates is pervasive, appearing in a variety of guises in the literature. The authors discuss the implications of persistence for theoretical models, illustrate existing findings with updated data, and highlight areas for future research. (JEL C22, E21, E44, E52, E62, G12)
\end{abstract}

Federal Reserve Bank of St. Louis Review, November/December 2008, 90(6), pp. 609-41.

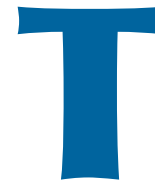

he real interest rate-an interest rate adjusted for either realized or expected inflation-is the relative price of consuming now rather than later. ${ }^{1}$ As such, it is a key variable in important theoretical models in finance and macroeconomics, such as the consumption-based asset pricing model (Lucas, 1978; Breeden, 1979; Hansen and Singleton, 1982, 1983), neoclassical growth model (Cass, 1965; Koopmans, 1965), models of central bank policy (Taylor, 1993), and numerous models of the monetary transmission mechanism.

The theoretical importance of the real interest rate has generated a sizable literature that exam-

1 Heterogeneous agents face different real interest rates, depending on horizon, credit risk, and other factors. And inflation rates are not unique, of course. For ease of exposition, this paper ignores such differences as being irrelevant to the economic inference. ines its long-run properties. This paper selectively reviews this literature, highlights its central findings, and analyzes their implications for theory. We illustrate our study with new empirical results based on U.S. data. Two themes emerge from our review: (i) Real rates are very persistent, much more so than consumption growth; and (ii) researchers should seriously explore the causes of this persistence.

First, empirical studies find that real interest rates exhibit substantial persistence, shown by extended periods when postwar real interest rates are substantially above or below the sample mean. Researchers characterize this feature of the data with several types of models. One group of studies uses unit root and cointegration tests to analyze whether shocks permanently affect the real interest rate-that is, whether the real rate behaves like a random walk. Such studies often report evidence

Christopher J. Neely is an assistant vice president and economist at the Federal Reserve Bank of St. Louis. David E. Rapach is an associate professor of economics at Saint Louis University. This project was undertaken while Rapach was a visiting scholar at the Federal Reserve Bank of St. Louis. The authors thank Richard Anderson, Menzie Chinn, Alan Isaac, Lutz Kilian, Miguel León-Ledesma, James Morley, Michael Owyang, Robert Rasche, Aaron Smallwood, Jack Strauss, and Mark Wohar for comments on earlier drafts and Ariel Weinberger for research assistance. The results reported in this paper were generated using GAUSS 6.1. Some of the GAUSS programs are based on code made available on the Internet by Jushan Bai, Christian Kleiber, Serena Ng, Pierre Perron, Katsumi Shimotsu, and Achim Zeileis, and the authors thank them for this assistance.

(C) 2008, The Federal Reserve Bank of St. Louis. The views expressed in this article are those of the author(s) and do not necessarily reflect the views of the Federal Reserve System, the Board of Governors, or the regional Federal Reserve Banks. Articles may be reprinted, reproduced, published, distributed, displayed, and transmitted in their entirety if copyright notice, author name(s), and full citation are included. Abstracts, synopses, and other derivative works may be made only with prior written permission of the Federal Reserve Bank of St. Louis. 
of unit roots, or-at a minimum-substantial persistence. Other studies extend standard unit root and cointegration tests by considering whether real interest rates are fractionally integrated or exhibit significant nonlinear behavior, such as threshold dynamics or nonlinear cointegration. Fractional integration tests typically indicate that real interest rates revert to their mean very slowly. Similarly, studies that find evidence of nonlinear behavior in real interest rates identify regimes in which the real rate behaves like a unit root process. Another important group of studies reports evidence of structural breaks in the means of real interest rates. Allowing for such breaks reduces the persistence of deviations from the regimespecific means, so breaks reduce local persistence. The structural breaks themselves, however, still produce substantial global persistence in real interest rates.

The empirical literature thus finds that persistence is pervasive. Although researchers have used sundry approaches to model persistence, certain approaches are likely to be more useful than others. Comprehensive model selection exercises are thus an important area for future research, as they will illuminate the exact nature of real interest rate persistence.

The second theme of our survey is that the literature has not adequately addressed the economic causes of persistence in real interest rates. Understanding such processes is crucial for assessing the relevance of different theoretical models. We discuss potential sources of persistence and argue that monetary shocks contribute to persistent fluctuations in real interest rates. While identifying economic structure is always challenging, exploring the underlying causes of real interest rate persistence is an especially important area for future research.

The rest of the paper is organized as follows. The next section reviews the predictions of economic and financial models for the long-run behavior of the real interest rate. This informs our discussion of the theoretical implications of the empirical literature's results. After distinguishing between ex ante and ex post measures of the real interest rate, the third section reviews papers that apply unit root, cointegration, fractional integration, and nonlinearity tests to real interest rates. The fourth section discusses studies of regime switching and structural breaks in real interest rates. The fifth section considers sources of the persistence in the U.S. real interest rate and ultimately argues that it is a monetary phenomenon. The sixth section summarizes our findings.

\section{THEORETICAL BACKGROUND}

\section{Consumption-Based Asset Pricing Model}

The canonical consumption-based asset pricing model of Lucas (1978), Breeden (1979), and Hansen and Singleton $(1982,1983)$ posits a representative household that chooses a real consumption sequence, $\left\{c_{t}\right\}_{t=0}^{\infty}$, to maximize

$$
\sum_{t=0}^{\infty} \beta^{t} u\left(c_{t}\right)
$$

subject to an intertemporal budget constraint, where $\beta$ is a discount factor and $u\left(c_{t}\right)$ is an instantaneous utility function. The first-order condition leads to the familiar intertemporal Euler equation,

$$
E_{t}\left\{\beta\left[u^{\prime}\left(c_{t+1}\right) / u^{\prime}\left(c_{t}\right)\right]\left(1+r_{t}\right)\right\}=1,
$$

where $1+r_{t}$ is the gross one-period real interest rate (with payoff at period $t+1$ ) and $E_{t}$ is the conditional expectation operator. Researchers often assume that the utility function is of the constant relative risk aversion form, $u\left(c_{t}\right)=c_{t}^{1-\alpha} /(1-\alpha)$, where $\alpha$ is the coefficient of relative risk aversion. Combining this with the assumption of joint lognormality of consumption growth and the real interest rate implies the log-linear version of the first-order condition given by equation (1) (Hansen and Singleton, 1982, 1983):

$$
\kappa-\alpha E_{t}\left[\Delta \log \left(c_{t+1}\right)\right]+E_{t}\left[\log \left(1+r_{t}\right)\right]=0,
$$

where $\Delta \log \left(c_{t+1}\right)=\log \left(c_{t+1}\right)-\log \left(c_{t}\right), \kappa=\log (\beta)+$ $0.5 \sigma^{2}$, and $\sigma^{2}$ is the constant conditional variance of $\log \left[\beta\left(c_{t+1} / c_{t}\right)^{-\alpha}\left(1+r_{t}\right)\right]$.

Equation (2) links the conditional expectations of the growth rate of real per capita consumption $\left[\Delta \log \left(c_{t+1}\right)\right]$ with the (net) real interest rate $\left[\log \left(1+r_{t}\right) \cong r_{t}\right]$. Rose (1988) argues that if equation (2) is to hold, then these two series must have 


\section{Figure 1}

\section{U.S. Ex Post Real Interest Rate and Real Per Capita Consumption Growth, 1953:Q1-2007:Q2}

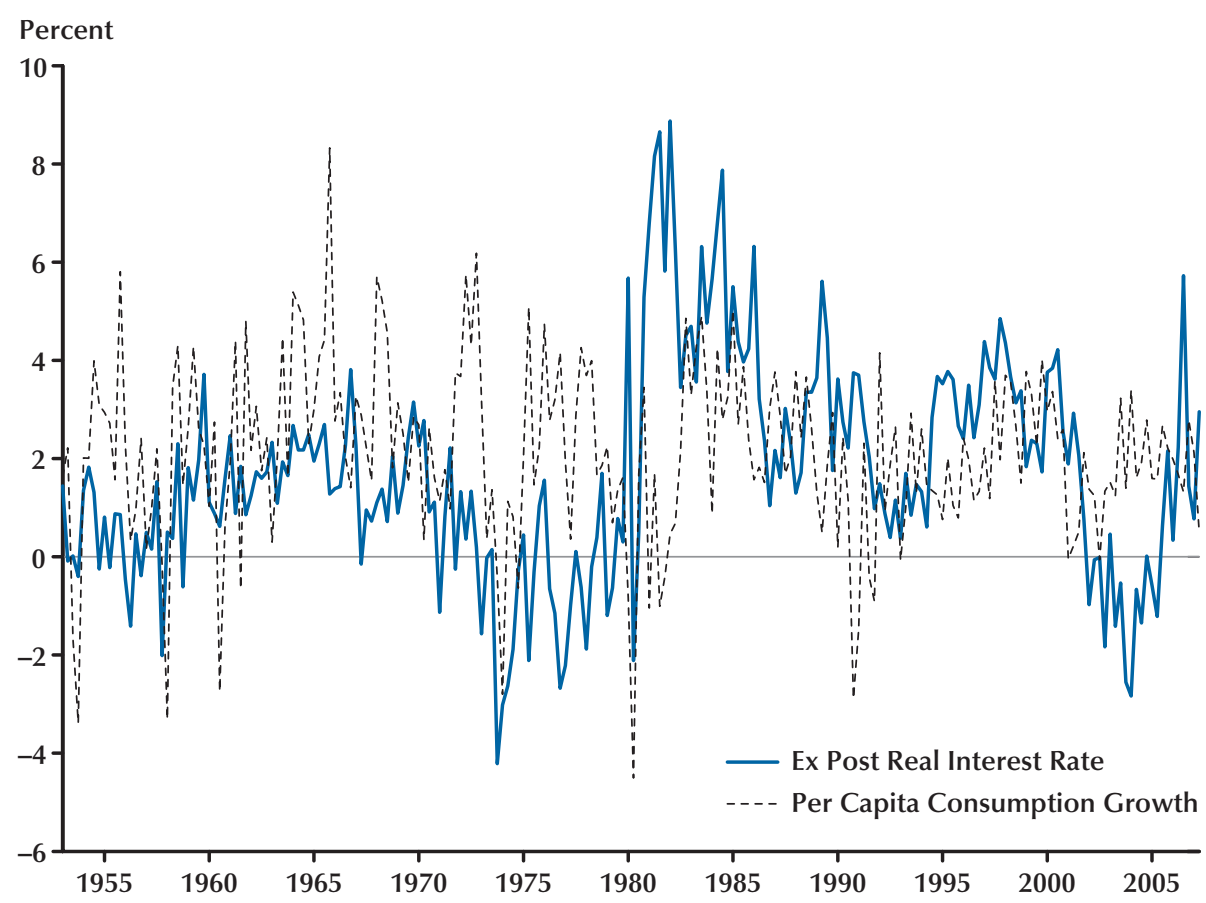

NOTE: The figure plots the U.S. ex post 3-month real interest rate and annualized per capita consumption growth. Consumption is measured as the sum of nondurable goods and services consumption.

similar integration properties. Whereas $\Delta \log \left(c_{t+1}\right)$ is almost surely a stationary process $\left[\Delta \log \left(c_{t+1}\right) \sim\right.$ $I(0)]$, Rose (1988) presents evidence that the real interest rate contains a unit root $\left[r_{t} \sim I(1)\right]$ in many industrialized countries. A unit root in the real interest rate combined with stationary consumption growth means that there will be permanent changes in the level of the real rate not matched by such changes in consumption growth, so equation (2) apparently cannot hold.

Figure 1 illustrates the problem identified by Rose (1988) using U.S. data for the ex post 3month real interest rate and annualized growth rate of per capita consumption (nondurable goods plus services) for 1953:Q1-2007:Q2. The two series appear to track each other reasonably well for long periods, such as the 1950s, 1960s, and 1984-2001, but they also diverge for significant periods, such as the 1970s, early 1980s, and 2001-05.
The simplest versions of the consumptionbased asset pricing model are based on an endowment economy with a representative household and constant preferences. The next subsection discusses the fact that more elaborate theoretical models allow for some changes in the economyfor example, changes in fiscal or monetary policy-to alter the steady-state real interest rate while leaving steady-state consumption growth unchanged. That is, they permit a mismatch in the integration properties of the real interest rate and consumption growth.

\section{Equilibrium Growth Models and the Steady-State Real Interest Rate}

General equilibrium growth models with a production technology imply Euler equations similar to equations (1) and (2) that suggest sources of a unit root in real interest rates. Specifically, the 


\section{Neely and Rapach}

Cass (1965) and Koopmans (1965) neoclassical growth model with a representative profitmaximizing firm and utility-maximizing household predicts that the steady-state real interest rate is a function of time preference, risk aversion, and the steady-state growth rate of technological change (Blanchard and Fischer, 1989, Chap. 2; Barro and Sala-i-Martin, 2003, Chap. 3; Romer, 2006, Chap. 2). In this model the assumption of constant relative risk aversion utility implies the following familiar steady-state condition:

$$
r^{*}=\zeta+\alpha z
$$

where $r^{*}$ is the steady-state real interest rate, $\zeta=-\log (\beta)$ is the rate of time preference, and $z$ is the (expected) steady-state growth rate of laboraugmenting technological change. Equation (3) implies that a permanent change in the exogenous rate of time preference, risk aversion, or long-run growth rate of technology will affect the steadystate real interest rate. ${ }^{2}$ If there is no uncertainty, the neoclassical growth model implies the following steady-state version of the Euler equation given by (2):

$$
-\zeta-\alpha[\Delta \log (c)]^{*}+r^{*}=0,
$$

where $[\Delta \log (c)]^{*}$ represents the steady-state growth rate of $c_{t}$. Substituting the right-hand side of equation (3) into equation (4) for $r^{*}$, one finds that steady-state technology growth determines steady-state consumption growth: $[\Delta \log (c)]^{*}=z$.

If the rate of time preference $(\zeta)$, risk aversion $(\alpha)$, and/or steady-state rate of technology growth ( $z$ ) change, then (3) requires corresponding changes in the steady-state real interest rate. Depending on the size and frequency of such changes, real interest rates might be very persis tent, exhibiting unit root behavior and/or structural breaks. Of these three factors, a change in the steady-state growth rate of technology-such as those that might be associated with the "productivity slowdown" of the early 1970s and/or the "New Economy" resurgence of the mid-1990s-is the only one that will alter both the real interest rate and consumption growth, producing non-

2 Changes in distortionary tax rates could also affect $r^{*}$ (Blanchard and Fischer, 1989, pp. 56-59). stationary behavior in both variables. Thus, it cannot explain the mismatch in the integration properties of the real interest rate and consumption growth identified by Rose (1988).

On the other hand, shocks to the preference parameters, $\zeta$ and $\alpha$, will change only the steadystate real interest rate and not steady-state consumption growth. Therefore, changes in preferences potentially disconnect the integration properties of real interest rates and consumption growth. Researchers generally view preferences as stable, however, making it unpalatable to ascribe the persistence mismatch to such changes. ${ }^{3}$

In more elaborate models, still other factors can change the steady-state real interest rate. For example, permanent changes in government purchases and their financing can also affect the steady-state real rate in overlapping generations models with heterogeneous households (Samuelson, 1958; Diamond, 1965; Blanchard, 1985; Blanchard and Fischer, 1989, Chap. 3; Romer, 2006, Chap. 2). Such shocks affect the steady-state real interest rate without affecting steady-state consumption growth, so they potentially explain the mismatch in the integration properties of the real interest rate and consumption growth examined by Rose (1988).

Finally, some monetary growth models allow for changes in steady-state money growth to affect the steady-state real interest rate. The seminal models of Mundell (1963) and Tobin (1965) predict that an increase in steady-state money growth lowers the steady-state real interest rate, and more recent micro-founded monetary models have similar implications (Weiss, 1980; Espinosa-Vega and Russell, 1998a,b; Bullard and Russell, 2004; Reis, 2007; Lioui and Poncet, 2008). Again, this class of models permits changes in the steadystate real interest rate without corresponding changes in consumption growth, potentially explaining a mismatch in the integration properties of the real interest rate and consumption growth.

\footnotetext{
3 Some researchers appear more willing to allow for changes in preferences over an extended period. For example, Clark (2007) argues that a steady decrease in the rate of time preference is responsible for the downward trend in real interest rates in Europe from the early medieval period to the eve of the Industrial Revolution.
} 


\section{Transitional Dynamics}

The previous section discusses factors that can affect the steady-state real interest rate. Other shocks can have persistent-but ultimately transitory-effects on the real rate. For example, in the neoclassical growth model, a temporary increase in technology growth or government purchases leads to a persistently (but not permanently) higher real interest rate (Romer, 2006, Chap. 2). In addition, monetary shocks can persistently affect the real interest rate via a variety of frictions, such as "sticky" prices and information, adjustment costs, and learning by agents about policy regimes. Transient technology and fiscal shocks, as well as monetary shocks, can also explain differences in the persistence of real interest rates and consumption growth. For example, using a calibrated neoclassical equilibrium growth model, Baxter and King (1993) show that a temporary (four-year) increase in government purchases persistently raises the real interest rate, although it eventually returns to its initial level. In contrast, the fiscal shock produces a much less persistent reaction in consumption growth. As we will discuss later, evidence of highly persistent but mean-reverting behavior in real interest rates supports the empirical relevance of these shocks.

\section{TESTING THE INTEGRATION PROPERTIES OF REAL INTEREST RATES}

\section{Ex Ante versus Ex Post Real Interest Rates}

The ex ante real interest rate (EARR) is the nominal interest rate minus the expected inflation rate, while the ex post real rate (EPRR) is the nominal rate minus actual inflation. Agents make economic decisions on the basis of their inflation expectations over the decision horizon. For example, the Euler equations (1) and (2) relate the expected marginal utility of consumption to the expected real return. Therefore, the EARR is the relevant measure for evaluating economic decisions, and we really wish to evaluate the EARR's time-series properties, rather than those of the EPRR.
Unfortunately, the EARR is not directly observable because expected inflation is not directly observable. An obvious solution is to use some survey measure of inflation expectations, such as the Livingston Survey of professional forecasters, which has been conducted biannually since the 1940s (Carlson, 1977). Economists are often reluctant, however, to accept survey forecasts as expectations. For example, Mishkin (1981, p. 153) expresses "serious doubts as to the quality of these [survey] data." Obtaining survey data at the desired frequency for the desired sample might create other obstacles to the use of survey data. Some studies have used survey data, however, including Crowder and Hoffman (1996) and Sun and Phillips (2004).

There are at least two alternative approaches to the problem of unobserved expectations. The first is to use econometric forecasting methods to construct inflation forecasts; see, for example, Mishkin $(1981,1984)$ and Huizinga and Mishkin (1986). Unfortunately, econometric forecasting models do not necessarily include all of the relevant information agents use to form expectations of inflation, and such models can fail to change with the structure of the economy. For example, Stock and Watson $(1999,2003)$ show that both real activity and asset prices forecast inflation but that the predictive relations change over time. ${ }^{4}$

A second alternative approach is to use the actual inflation rate as a proxy for inflation expectations. By definition, the actual inflation rate at time $t\left(\pi_{t}\right)$ is the sum of the expected inflation rate and a forecast error term $\left(\varepsilon_{t}\right)$ :

$$
\pi_{t}=E_{t-1} \pi_{t}+\varepsilon_{t}
$$

The literature on real interest rates has long argued that, if expectations are formed rationally, $E_{t-1} \pi_{t}$ should be an optimal forecast of inflation (Nelson and Schwert, 1977), and $\varepsilon_{t}$ should there-

\footnotetext{
4 Atkeson and Ohanian (2001) and Stock and Watson (2007) discuss the econometric challenges in forecasting inflation. One might also consider using Treasury inflation-protected securities (TIPS) yields-and/or their foreign counterparts-to measure real interest rates. But these series have a relatively short span of available data, in that the U.S. securities were first issued in 1997, are only available at long maturities $(5,10$, and 20 years), and do not correctly measure real rates when there is a significant chance of deflation.
} 


\section{Neely and Rapach}

fore be a white noise process. The EARR can be expressed (approximately) as

$$
r_{t}^{e a}=i_{t}-E_{t} \pi_{t+1},
$$

where $i_{t}$ is the nominal interest rate. Solving equation (5) for $E_{t}\left(\pi_{t+1}\right)$ and substituting it into equation (6), we have

$$
\begin{aligned}
r_{t}^{e a} & =i_{t}-\left(\pi_{t+1}-\varepsilon_{t+1}\right) \\
& =i_{t}-\pi_{t+1}+\varepsilon_{t+1}=r_{t}^{e p}+\varepsilon_{t+1},
\end{aligned}
$$

where $r_{t}^{e p}=i_{t}-\pi_{t+1}$ is the EPRR. Equation (7) implies that, under rational expectations, the EPRR and EARR differ only by a white noise component, so the EPRR and EARR will share the same long-run (integration) properties. Actually, this latter result does not require expectations to be formed rationally but holds if the expectation errors $\left(\varepsilon_{t+1}\right)$ are stationary. ${ }^{5}$ Beginning with Rose (1988), much of the empirical literature tests the integration properties of the EARR with the EPRR, after assuming that inflation-expectation errors are stationary.

Researchers typically evaluate the integration properties of the EPRR with a decision rule. They first analyze the individual components of the EPRR, $i_{t}$ and $\pi_{t+1}$. If unit root tests indicate that $i_{t}$ and $\pi_{t+1}$ are both $I(0)$, then this implies a stationary EPRR, as any linear combination of two $I(0)$ processes is also an $I(0)$ process. ${ }^{6}$ If $i_{t}$ and $\pi_{t+1}$ have different orders of integration-for example, if $i_{t} \sim I(1)$ and $\pi_{t+1} \sim I(0)$-then the EPRR must have a unit root, as any linear combination of an $I(1)$ process and an $I(0)$ process is an $I(1)$ process. Finally, if unit root tests show that $i_{t}$ and $\pi_{t+1}$ are both $I(1)$, researchers test for a stationary EPRR by testing for cointegration between $i_{t}$ and $\pi_{t+1}-$ that is, testing whether the linear combination

\footnotetext{
5 Peláez (1995) provides evidence that inflation-expectation errors are stationary. Also note that Andolfatto, Hendry, and Moran (2008) argue that inflation-expectation errors can appear serially correlated in finite samples, even when expectations are formed rationally, due to short-run learning dynamics about infrequent changes in the monetary policy regime.

6 The appendix, "Unit Roots and Cointegration Tests," provides more information on the mechanics of popular unit root and cointegration tests.

7 The presence of $\theta_{0}$ allows for a constant term in the cointegrating relationship corresponding to the steady-state real interest rate.
}

$i_{t}-\left[\theta_{0}+\theta_{1} \pi_{t+1}\right]$ is a stationary process-using one of two approaches. ${ }^{7}$ First, many researchers impose a cointegrating vector of $\left(1,-\theta_{1}\right)^{\prime}=(1,-1)^{\prime}$ and apply unit root tests to $r_{t}^{e p}=i_{t}-\pi_{t+1}$. This approach typically has more power to reject the null of no cointegration when the true cointegrating vector is $(1,-1)^{\prime}$. The second approach is to freely estimate the cointegrating vector between $i_{t}$ and $\pi_{t+1}$, as this allows for tax effects (Darby, 1975).

If $i_{t}, \pi_{t+1} \sim I(1)$, then a stationary EPRR requires $i_{t}$ and $\pi_{t+1}$ to be cointegrated with cointegrating coefficient, $\theta_{1}=1$, or, allowing for tax effects, $\theta_{1}=1 /(1-\tau)$, where $\tau$ is the marginal investor's marginal tax rate on nominal interest income. When allowing for tax effects, researchers view estimates of $\theta_{1}$ in the range of 1.3 to 1.4 as plausible, as they correspond to a marginal tax rate around 0.2 to 0.3 (Summers, 1983). ${ }^{8}$ It is worth emphasizing that cointegration between $i_{t}$ and $\pi_{t+1}$ by itself does not imply a stationary real interest rate: $\theta_{1}$ must also equal 1 [or $1 /(1-\tau)$ ], as other values of $\theta_{1}$ imply that the equilibrium real interest rate varies with inflation.

Although much of the empirical literature analyzes the EPRR in this manner, it is important to keep in mind that the EPRR's time-series properties can differ from those of the EARR-the ultimate object of analysis-in two ways. First, the EPRR's behavior at short horizons might differ from that of the EARR. For example, using survey data and various econometric methods to forecast inflation, Dotsey, Lantz, and Scholl (2003) study the behavior of the EARR and EPRR at businesscycle frequencies and find that their behavior over the business cycle can differ significantly. Second, some estimation techniques can generate different persistence properties between the EARR and EPRR; see, for example, Evans and Lewis (1995) and Sun and Phillips (2004).

\section{Early Studies}

A collection of early studies on the efficient market hypothesis and the ability of nominal

\footnotetext{
${ }^{8}$ Data from tax-free municipal bonds would presumably provide a unitary coefficient. Crowder and Wohar (1999) study the Fisher effect with tax-free municipal bonds.
} 
interest rates to forecast the inflation rate foreshadows the studies that use unit root and cointegration tests. Fama (1975) presents evidence that the monthly U.S. EARR can be viewed as constant over 1953-71. Nelson and Schwert (1977), however, argue that statistical tests of Fama (1975) have low power and that his data are actually not very informative about the EARR's autocorrelation properties. Hess and Bicksler (1975), Fama (1976), Carlson (1977), and Garbade and Wachtel (1978) also challenge Fama's (1975) finding on statistical grounds. In addition, subsequent studies show that Fama's (1975) result hinges critically on the particular sample period (Mishkin, 1981, 1984; Huizinga and Mishkin, 1986; Antoncic, 1986).

\section{Unit Root and Cointegration Tests}

The development of unit root and cointegration analysis, beginning with Dickey and Fuller (1979), spurred the studies that formally test the persistence of real interest rates. In his seminal study, Rose (1988) tests for unit roots in short-term nominal interest rates and inflation rates using monthly data for 1947-86 for 18 countries in the Organisation for Economic Co-operation and Development (OECD). Rose (1988) finds that augmented Dickey-Fuller (ADF) tests fail to reject the null hypothesis of a unit root in short-term nominal interest rates, but they can consistently reject a unit root in inflation rates based on various price indices-consumer price index (CPI), gross national product (GNP) deflator, implicit price deflator, and wholesale price index (WPI) ${ }^{9}$ As discussed above, the finding that $i_{t} \sim I(1)$ while $\pi_{t} \sim I(0)$ indicates that the EPRR, $i_{t}-\pi_{t+1}$, is an $I(1)$ process. Under the assumption that inflationexpectation errors are stationary, this also implies that the EARR is an I(1) process. Rose (1988) easily rejects the unit root null hypothesis for U.S. consumption growth, which leads him to argue that an $I(1)$ real interest rate and $I(0)$ consumption growth rate violates the intertemporal Euler equation implied by the consumption-based asset pricing model. Beginning with Rose (1988), Table 1 summarizes the methods and conclusions of sur-

9 The appendix discusses unit root and cointegration tests. veyed papers on the long-run properties of real interest rates.

A number of subsequent papers also test for a unit root in real interest rates. Before estimating structural vector autoregressive (SVAR) models, King et al. (1991) and Galí (1992) apply ADF unit root tests to the U.S. nominal 3-month Treasury bill rate, inflation rate, and EPRR. Using quarterly data for 1954-88 and the GNP deflator inflation rate, King et al. (1991) fail to reject the null hypothesis of a unit root in the nominal interest rate, matching the finding of Rose (1988). Unlike Rose (1988), however, King et al. cannot reject the unit root null hypothesis for the inflation rate, which creates the possibility that the nominal interest rate and inflation rate are cointegrated. Imposing a cointegrating vector of $(1,-1)^{\prime}$, they fail to reject the unit root null hypothesis for the EPRR. Using quarterly data for 1955-87, the CPI inflation rate, and simulated critical values that account for potential size distortions due to moving-average components, Galí (1992) obtains unit root test results similar to those of King et al. Despite the failure to reject the null hypothesis that $i_{t}-\pi_{t+1} \sim$ $I(1)$, Galí nevertheless assumes that $i_{t}-\pi_{t+1} \sim I(0)$ when he estimates his SVAR model, contending that "the assumption of a unit root in the real [interest] rate seems rather implausible on a priori grounds, given its inconsistency with standard equilibrium growth models” (Galí, 1992, p. 717). This is in interesting contrast to King et al., who maintain the assumption that $i_{t}-\pi_{t+1} \sim I(1)$ in their SVAR model. Shapiro and Watson (1988) report similar unit root findings and, like Galí, still assume the EPRR is stationary in an SVAR model.

Analyzing a 1953-90 full sample, as well as a variety of subsamples for the nominal Treasury bill rate and CPI inflation rate, Mishkin (1992) argues that monthly U.S. data are largely consistent with a stationary EPRR. With simulated critical values, as in Galí (1992), Mishkin (1992) finds that the nominal interest rate and inflation rate are both I(1) over four sample periods: 1953:011990:12, 1953:01-1979:10, 1979:11-1982:10, and 1982:11-1990:12. He then tests whether the nominal interest rate and inflation rate are cointegrated using both the single-equation augmented Engle and Granger (1987, AEG) test and by prespecify- 
Table 1

Selective Summary of the Empirical Literature on the Long-Run Properties of Real Interest Rates

\begin{tabular}{|c|c|c|c|}
\hline Study & Sample & Countries & Nominal interest rate and price data \\
\hline Rose (1988) & $\begin{array}{c}\text { A: } 1892-70,1901-50 \\
\text { Q: } 1947-86 \\
\text { M: } 1948-86\end{array}$ & 18 OECD countries & $\begin{array}{l}\text { Long-term corporate bond yield, short- } \\
\text { term commercial paper rate, GNP } \\
\text { deflator, CPI, implicit price deflator, WPI }\end{array}$ \\
\hline King et al. (1991) & Q: 1949-88 & U.S. & $\begin{array}{l}\text { 3-month U.S. Treasury bill rate, implicit } \\
\text { GNP deflator }\end{array}$ \\
\hline Galí (1992) & Q: 1955-87 & U.S. & 3-month U.S. Treasury bill rate, CPI \\
\hline Mishkin (1992) & M: 1953-90 & U.S. & 1- and 3-month Treasury bill rates, CPI \\
\hline
\end{tabular}

\begin{tabular}{|c|c|c|c|}
\hline $\begin{array}{l}\text { Wallace and Warner } \\
\text { (1993) }\end{array}$ & Q: 1948-90 & U.S. & $\begin{array}{l}\text { 3-month Treasury bill rate, } 10 \text {-year } \\
\text { government bond yield, CPI }\end{array}$ \\
\hline Engsted (1995) & Q: 1962-93 & 13 OECD countries & Long-term bond yield, CPI \\
\hline $\begin{array}{l}\text { Mishkin and Simon } \\
\text { (1995) }\end{array}$ & Q: 1962-93 & Australia & 13-week government bond yield, CPI \\
\hline $\begin{array}{l}\text { Crowder and Hoffman } \\
\text { (1996) }\end{array}$ & Q: 1952-91 & U.S. & $\begin{array}{l}\text { 3-month Treasury bill rate, implicit } \\
\text { consumption deflator, Livingston } \\
\text { inflation expectations survey, tax data } \\
\text { from various sources }\end{array}$ \\
\hline $\begin{array}{l}\text { Koustas and Serletis } \\
\text { (1999) }\end{array}$ & $\begin{array}{l}\text { Q: Data begin from } \\
\text { 1957-72; all data } \\
\text { end in } 1995\end{array}$ & 11 OECD countries & $\begin{array}{l}\text { Various short-term nominal interest rates, } \\
\mathrm{CPI}\end{array}$ \\
\hline Bierens (2000) & M: 1954-94 & U.S. & Federal funds rate, $\mathrm{CPI}$ \\
\hline Rapach (2003) & $\begin{array}{l}\text { A: Data begin in } \\
\text { 1949-65; end in } \\
\text { 1994-96 }\end{array}$ & 14 industrialized countries & $\begin{array}{l}\text { Long-term government bond yield, } \\
\text { implicit GDP deflator }\end{array}$ \\
\hline $\begin{array}{l}\text { Rapach and Weber } \\
(2004)\end{array}$ & Q: 1957-2000 & 16 OECD countries & Long-term government bond yield, CPI \\
\hline $\begin{array}{l}\text { Rapach and Wohar } \\
(2004)\end{array}$ & Q: 1960-1998 & 13 OECD countries & $\begin{array}{l}\text { Long-term government bond yield, CPI } \\
\text { marginal tax rate data (Padovano and } \\
\text { Galli, 2001) }\end{array}$ \\
\hline
\end{tabular}

NOTE: A, Q, and M indicate annual, quarterly, and monthly data frequencies; GNP denotes gross national product. 


\section{Results on the long-run properties of nominal interest rates, inflation rates, and real interest rates}

ADF tests fail to reject a unit root for nominal interest rates but do reject for inflation rates, indicating a unit root in EPRRs. ADF tests do reject a unit root for consumption growth.

ADF tests fail to reject a unit root for the nominal interest rate, inflation rate, and EPRR.

ADF tests with simulated critical values that adjust for moving-average components fail to reject a unit root in the nominal interest rate, inflation rate, and EPRR.

ADF tests with simulated critical values that adjust for moving-average components fail to reject a unit root in the nominal interest rate and inflation rate. AEG tests typically reject the null of no cointegration, indicating a stationary EPRR.

ADF tests fail to reject a unit root in the long-term nominal interest rate and inflation rate. Johansen (1991) procedure provides evidence that the variables are cointegrated and that the EPRR is stationary.

ADF tests fail to reject a unit root in nominal interest rates and inflation rates, while cointegration tests present ambiguous results on the stationarity of the EPRR across countries.

ADF tests fail to reject a unit root in the nominal interest rate and inflation rate. AEG tests typically fail to reject the null hypothesis of no cointegration, indicating a nonstationary EPRR.

ADF test fails to reject a unit root in the nominal interest rate and inflation rate after accounting for moving-average components. Johansen (1991) procedure rejects the null of no cointegration and supports a stationary EPRR.

ADF tests usually fail to reject a unit root in nominal interest rates and inflation rates, while KPSS tests typically reject the null of stationarity, indicating nonstationary nominal interest rates and inflation rates. AEG tests typically fail to reject the null of no cointegration, indicating a nonstationary EPRR.

New test provides evidence of nonlinear cotrending between the nominal interest rate and inflation rate, indicating a stationary EPRR. New test, however, cannot distinguish between nonlinear cotrending and linear cointegration.

ADF tests fail to reject a unit root in all nominal interest rates and in 13 of 17 inflation rates. This indicates a nonstationary EPRR for the four countries with a stationary inflation rate. AEG tests typically fail to reject a unit root in the EPRR for the 13 countries with a nonstationary inflation rate, indicating a nonstationary EPRR for these countries.

$\mathrm{Ng}$ and Perron (2001) unit root tests typically fail to reject a unit root in nominal interest rates and inflation rates. $\mathrm{Ng}$ and Perron (2001) and Perron and Rodriguez (2001) tests usually fail to reject the null of no cointegration, indicating a nonstationary EPRR in most countries.

Lower (upper) 95 percent confidence band for the EPRR's $\rho$ is close to 0.90 (above unity) for nearly every country. 


\section{Neely and Rapach}

\section{Table 1, cont'd}

\section{Selective Summary of the Empirical Literature on the Long-Run Properties of Real Interest Rates}

\begin{tabular}{|c|c|c|c|}
\hline Study & Sample & Countries & Nominal interest rate and price data \\
\hline $\begin{array}{l}\text { Karanasos, Sekioua, } \\
\text { and Zeng (2006) }\end{array}$ & A: $1876-2000$ & U.S. & Long-term government bond yield, CPI \\
\hline Lai (1997) & Q: 1974-2001 & $\begin{array}{l}8 \text { industrialized and } \\
8 \text { developing countries }\end{array}$ & $\begin{array}{l}\text { 1- to } 12-\text { month Treasury bill rates, CPI, } \\
\text { Data Resources, Inc. inflation forecasts }\end{array}$ \\
\hline Tsay (2000) & M: 1953-90 & U.S. & 1- and 3-month Treasury bill rates, CPI \\
\hline Sun and Phillips (2004) & Q: 1934-94 & U.S. & $\begin{array}{l}\text { 3-month Treasury bill rate, inflation } \\
\text { forecasts from the Survey of } \\
\text { Professional Forecasters, CPI }\end{array}$ \\
\hline $\begin{array}{l}\text { Pipatchaipoom and } \\
\text { Smallwood (2008) }\end{array}$ & M: 1971-2003 & U.S. & Eurodollar rate, $\mathrm{CPI}$ \\
\hline Maki (2003) & M: 1972-2000 & Japan & 10-year bond rate, call rate, $\mathrm{CPI}$ \\
\hline
\end{tabular}

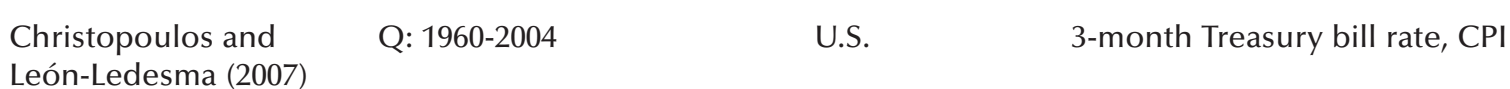

León-Ledesma (2007)

Koustas and Lamarche A: 1960-2004 G-7 countries 3-month government bill rate, CPI
(2008)

Garcia and Perron (1996)

Q: 1961-86

U.S.

3-month Treasury bill rate, CPI

Clemente, Montañés, Q: 1980-95 U.S., U.K. $\quad$ Long-term government bond yield, CPI and Reyes (1998)

Caporale and Grier (2000) Q: 1961-86

U.S.

3-month Treasury bill rate, CPI

Bai and Perron (2003)

Q: 1961-86

U.S.

3-month Treasury bill rate, CPI

NOTE: A, Q, and M indicate annual, quarterly, and monthly data frequencies; GNP denotes gross national product. 
Results on the long-run properties of nominal interest rates, inflation rates, and real interest rates

95 percent confidence interval for the EPRR's $\rho$ is $(0.97,0.99)$. There is evidence of long-memory, mean-reverting behavior in the EPRR.

ADF and KPSS tests indicate a unit root in the nominal interest rate, inflation rate, and expected inflation rate. There is evidence of long-memory, mean-reverting behavior in the EARR and EPRR.

There is evidence of long-memory, mean-reverting behavior in the EPRR.

Bivariate exact Whittle estimator indicates long-memory behavior in the EARR. There is no evidence of a fractional cointegrating relationship between the nominal interest rate and expected inflation rate.

Exact Whittle estimator provides evidence of long-memory, mean-reverting behavior in the EARR.

Breitung (2002) nonparametric test that allows for nonlinear short-run dynamics provides evidence of cointegration between the nominal interest rate and inflation rate; cointegrating vector is not estimated, however, so it is not known if the cointegrating relationship is consistent with a stationary EPRR.

Luukkonen, Saikkonen, and Teräsvirta (1988) test rejects linear short-run dynamics for the adjustment to the longrun equilibrium EPRR. A smooth transition autoregressive model exhibits asymmetric mean reversion in the EPRR, depending on the level of the EPRR.

Choi and Saikkonen (2005) test provides evidence of nonlinear cointegration between the nominal interest rate and inflation rate. Exponential smooth transition regression (ESTR) model fits best over the full sample and the first subsample (1960-78), while a logistic smooth transition regression (LSTR) model fits best over the second subsample (1979-2004). Estimated ESTR model for 1960-78 is not consistent with a stationary EPRR for any inflation rate, and estimated LSTR model for 1979-2004 is consistent with a stationary EPRR only when the inflation rate is above approximately 3 percent.

ADF and KPSS tests provide evidence of a unit root in the nominal interest rate and inflation rate. Bec, Ben Salem, and Carassco $(2004)$ nonlinear unit root and Hansen $(1996,1997)$ linearity tests indicate that the EPRR can be suitably modeled as a three-regime self-exciting autoregressive (SETAR) process in Canada, France, and Italy.

An estimated autoregressive model with a three-state Markov-switching process for the mean indicates that the EPRR was in a "moderate"-mean regime for 1961-73, a "low"-mean regime for 1973-80, and a "high"-mean regime for 1980-86. EPRR is stationary with little persistence within these regimes.

ADF tests that allow for two structural breaks in the mean reject a unit root in the EPRR, indicating that the EPRR is stationary within regimes defined by structural breaks.

Bai and Perron (1998) methodology provides evidence of multiple structural breaks in the mean EPRR.

Bai and Perron (1998) methodology provides evidence of multiple structural breaks in the mean EPRR. 


\section{Table 1, cont'd}

\section{Selective Summary of the Empirical Literature on the Long-Run Properties of Real Interest Rates}

\begin{tabular}{|c|c|c|c|}
\hline Study & Sample & Countries & Nominal interest rate and price data \\
\hline Lai (2004) & M: 1978-2002 & U.S. & $\begin{array}{l}\text { 1-year Treasury bill rate, inflation } \\
\text { expectations from the University of } \\
\text { Michigan Survey of Consumers, CPI, } \\
\text { federal marginal income tax rates for } \\
\text { four-person families }\end{array}$ \\
\hline
\end{tabular}

$\begin{array}{lccc}\text { Rapach and Wohar (2005) Q: 1960-98 } & \text { 13 OECD countries } & \begin{array}{l}\text { Long-term government bond yield, } \\ \text { CPI, marginal tax rate data (Padovano } \\ \text { and Galli, 2001) }\end{array} \\ \text { Lai (2008) } & \text { Q: 1974-2001 } & \begin{array}{l}8 \text { industrialized and } \\ 8 \text { developing countries }\end{array} & \begin{array}{c}\text { 1- to 12-month Treasury bill rate, deposit } \\ \text { rate, CPI }\end{array}\end{array}$

NOTE: A, Q, and M indicate annual, quarterly, and monthly data frequencies; GNP denotes gross national product.

ing a cointegrating vector and testing for a unit root in $i_{t}-\pi_{t+1}$. Mishkin (1992) rejects the null hypothesis of no cointegration for the 1953:011990:12 and 1953:01-1979:10 periods, but finds less frequent and weaker rejections for the 1979:11-1982:10 and 1982:11-1990:12 periods. ${ }^{10}$ Mishkin and Simon (1995) apply similar tests to quarterly short-term nominal interest rate and inflation rate data for Australia. Using a 1962:Q31993:Q4 full sample, as well as 1962:Q3-1979:Q3 and 1979:Q4- 1993:Q4 subsamples, they find evidence that both the nominal interest rate and the inflation rate are $I(1)$, agreeing with the results for U.S. data in Mishkin (1992). There is weaker evidence that the Australian nominal interest rate and inflation rate are cointegrated than there is for U.S. data. Nevertheless, Mishkin and Simon (1995) argue that theoretical considerations warrant viewing the long-run real interest rate as stationary in Australia, as "any reasonable model of the macro economy would surely suggest that

\footnotetext{
${ }^{10}$ Although they use essentially the same econometric procedures and similar samples, Galí (1992) is unable to reject the unit root null hypothesis for the EPRR, while Mishkin (1992) does reject this null hypothesis. This illustrates the sensitivity of EPRR unit root and cointegration tests to the specific sample. In addition, the use of short samples, such as the 1979:11-1982:10 sample period considered by Mishkin (1992), is unlikely to be informative about the integration properties of the EPRR. To infer long-run behavior, one needs reasonably long samples.
}

real interest rates have mean-reverting tendencies which make them stationary" (Mishkin and Simon, 1995, p. 223).

Koustas and Serletis (1999) test for unit roots and cointegration in short-term nominal interest rates and CPI inflation rates using quarterly data for 1957-95 for 11 industrialized countries. They use ADF unit root tests as well as the KPSS unit root test of Kwiatkowski et al. (1992), which takes stationarity as the null hypothesis and nonstationarity as the alternative. ADF and KPSS unit root tests indicate that $i_{t} \sim I(1)$ and $\pi_{t+1} \sim I(1)$ in most countries, so a stationary EPRR requires cointegration between the nominal interest rate and inflation rate. Koustas and Serletis (1999), however, usually fail to find strong evidence of cointegration using the AEG test. Overall, their study finds that the EPRR is nonstationary in many industrialized countries. Rapach (2003) obtains similar results using postwar data for an even larger number of OECD countries.

In a subtle variation on conventional cointegration analysis, Bierens (2000) allows an individual time series to have a deterministic component that is a highly complex function of time-essentially a smooth spline-and a stationary stochastic component, and he develops nonparametric procedures to test whether two series share a common 
Results on the long-run properties of nominal interest rates, inflation rates, and real interest rates

ADF tests allowing for a structural break in the mean reject a unit root in the tax-adjusted or unadjusted EARR, indicating that the EARR is stationary within regimes defined by the structural break.

The Bai and Perron (1998) methodology provides evidence of structural breaks (usually multiple) in the mean EPRR and mean inflation rate for all 13 countries.

ADF tests allowing for a structural break in the mean reject a unit root in the EPRR for most countries, indicating that the EPRR is stationary within regimes defined by the structural break.

deterministic component ("nonlinear cotrending”). Using monthly U.S. data for 1954-94, Bierens (2000) presents evidence that the federal funds rate and CPI inflation rate cotrend with a vector of $(1,-1)^{\prime}$, which can be interpreted as evidence for a stationary real interest rate. Bierens shows, however, that his tests cannot differentiate between nonlinear cotrending and linear cointegration in the presence of stochastic trends in the nominal interest rate and inflation rate. In essence, the highly complex deterministic components for the individual series closely mimic unit root behavior.

A number of studies use the Johansen (1991) system-based cointegration procedure to test for a stationary EPRR. Wallace and Warner (1993) apply the Johansen (1991) procedure to quarterly U.S. nominal 3-month Treasury bill rate and CPI inflation data for a 1948-90 full sample and a number of subsamples. Their results generally support the existence of a cointegrating relationship, and their estimates of $\theta_{1}$ are typically not significantly different from unity, in line with a stationary EPRR. Wallace and Warner (1993) also argue that the expectations hypothesis implies that short-term and long-term nominal interest rates should be cointegrated, and they find evidence that U.S. short and long rates are cointe- grated with a cointegrating vector of $(1,-1)^{\prime}$. In line with the results for the nominal 3-month Treasury bill rate, Wallace and Warner find that the nominal 10-year Treasury bond rate and inflation rate are cointegrated.

With quarterly U.S. data for 1951-91, Crowder and Hoffman (1996) also use the Johansen (1991) procedure to test for cointegration between the 3-month Treasury bill rate and implicit consumption deflator inflation rate. As in Wallace and Warner (1993), they reject the null of no cointegration between the nominal interest rate and inflation rate. Their estimates of $\theta_{1}$ range from 1.22 to 1.34 , which are consistent with a stationary tax-adjusted EPRR. Crowder and Hoffman (1996) also use estimates of average marginal tax rates to directly test for cointegration between $i_{t}(1-\tau)$ and $\pi_{t+1}$. The Johansen (1991) procedure supports cointegration and estimates a cointegrating vector not significantly different from $(1,-1)^{\prime}$, in line with a stationary tax-adjusted EPRR.

Engsted (1995) uses the Johansen (1991) procedure to test for cointegration between the nominal long-term government bond yield and CPI inflation rate in 13 OECD countries using quarterly data for 1962-93. In broad agreement with the results of Wallace and Warner (1993) and Crowder and Hoffman (1996), Engsted (1995) rejects the 
Table 2

Unit Root Test Statistics, U.S. data, 1953:Q1-2007:Q2

\begin{tabular}{llc} 
Variable & ADF & $\mathbf{M Z}_{\alpha}$ \\
\hline 3-Month Treasury bill rate & $-2.49[7]$ & $-4.39[8]$ \\
PCE deflator inflation rate & $-2.72^{*}[4]$ & $-5.20[5]$ \\
Ex post real interest rate & $-3.06^{* *}[6]$ & $-18.83^{* * *}[2]$ \\
Per capita consumption growth & $-4.99^{* * *}[4]$ & $-42.07^{* * *}[2]$
\end{tabular}

NOTE: The ADF and $M Z_{\alpha}$ statistics correspond to a one-sided (lower-tail) test of the null hypothesis that the variable has a unit root against the alternative hypothesis that the variable is stationary. The 10 percent, 5 percent, and 1 percent critical values for the ADF statistic are $-2.58,-2.89$, and -3.51 ; the 10 percent, 5 percent, and 1 percent critical values for the $M Z_{\alpha}$ statistic are $-5.70,-8.10$, and -13.80. The lag order for the regression model used to compute the test statistic is reported in brackets. ${ }^{*}, * *$, and ${ }^{* * *}$ indicate significance at the 10 percent, 5 percent, and 1 percent levels. PCE denotes personal consumption expenditures.

null hypothesis of no cointegration for almost all countries. The estimates of $\theta_{1}$ vary quite markedly across countries, however, and the values are often inconsistent with a stationary EPRR.

Overall, unit root and cointegration tests present mixed results with respect to the integration properties of the EPRR. Generally speaking, single-equation methods provide weaker evidence of a stationary EPRR, while the Johansen (1991) system-based approach supports a stationary EPRR, at least for the United States. Unfortunately, econometric issues, such as the low power of unit root tests and size distortions in the presence of moving-average components, complicate inference about persistence.

To address these econometric issues, Rapach and Weber (2004) use unit root and cointegration tests with improved size and power. Specifically, they use the Ng and Perron (2001) unit root and Perron and Rodriguez (2001) cointegration tests. These tests incorporate aspects of the modified ADF tests in Elliott, Rothenberg, and Stock (1996) and Perron and Ng (1996), as well as an adjusted modified information criterion to select the autoregressive (AR) lag order, to develop tests that avoid size distortions while retaining power. Rapach and Weber (2004) use quarterly nominal long-term government bond yield and CPI inflation rate data for 1957-2000 for 16 industrialized countries. The Ng and Perron (2001) unit root and Perron and Rodriguez (2001) cointegration tests provide mixed results, but Rapach and Weber interpret their results as indicating that the EPRR is nonstationary in most industrialized countries over the postwar era.

\section{Updated Unit Root and Cointegration Test Results for U.S. Data}

Tables 2 and 3 illustrate the type of evidence provided by unit root and cointegration tests for the U.S. 3-month Treasury bill rate, CPI inflation rate, and per capita consumption growth rate for 1953:Q1-2007:Q2 (the same data as in Figure 1).

Table 2 reports the ADF statistic, as well as the $M Z_{\alpha}$ statistic from Ng and Perron (2001), which is designed to have better size and power properties than the former. Consistent with the literature, neither test rejects the unit root null hypothesis for the nominal interest rate. The results are mixed for the inflation rate: The ADF statistic rejects the unit root null at the 10 percent level, but the $M Z_{\alpha}$ statistic does not reject at conventional significance levels. The ADF test result that $i_{t} \sim I(1)$ while $\pi_{t} \sim I(0)$ means that the EPRR is nonstationary, as in Rose (1988). ${ }^{11}$ The $M Z_{\alpha}$ statistic's failure to reject the unit root null for either inflation or nomi-

\footnotetext{
${ }^{11}$ A significant moving-average component in the inflation rate could create size distortions in the ADF statistic that lead us to falsely reject the unit root null hypothesis for that series. The fact that we do not reject the unit root null using the $M Z_{\alpha}$ statistic-which is designed to avoid this size distortion-supports this interpretation. Rapach and Weber (2004), however, do reject the unit root null for the U.S. inflation rate using the $M Z_{\alpha}$ statistic and data through 2000. Inflation rate unit root tests are thus particularly sensitive to the sample period.
} 


\section{Table 3}

\section{Cointegration Test Statistics and Cointegrating Coefficient Estimates, U.S. 3-Month Treasury Bill Rate and Inflation Rate (1953:Q1-2007:Q2)}

\begin{tabular}{|c|c|c|}
\hline \multicolumn{3}{|l|}{ Cointegration tests } \\
\hline AEG & $M Z_{\alpha}$ & Trace \\
\hline$-3.07 *[6]$ & $-17.11 * *[2]$ & $19.96 *[4]$ \\
\hline \multicolumn{3}{|l|}{ Coefficient estimates } \\
\hline Estimation method & $\theta_{0}$ & $\theta_{1}$ \\
\hline Dynamic OLS & $2.16^{* *}(1.01)$ & $0.86^{* * *}(0.24)$ \\
\hline Johansen (1991) maximum likelihood & $0.39(1.21)$ & $1.44^{* * *}(0.29)$ \\
\hline
\end{tabular}

NOTE: The AEG and $M Z_{\alpha}$ statistics correspond to a one-sided (lower-tail) test of the null hypothesis that the 3-month Treasury bill rate and inflation rate are not cointegrated against the alternative hypothesis that the variables are cointegrated. The 10 percent, 5 percent, and 1 percent critical values for the AEG statistic are $-3.07,-3.37$, and -3.96 ; the 10 percent, 5 percent, and 1 percent critical values for the $M Z_{\alpha}$ statistic are $-12.80,-15.84$, and -22.84 . The trace statistic corresponds to a one-sided (upper-tail) test of the null hypothesis that the 3-month Treasury bill rate and inflation rate are not cointegrated against the alternative hypothesis that the variables are cointegrated. The 10 percent, 5 percent, and 1 percent critical values for the trace statistic are 18.47, 20.66, and 24.18. The lag order for the regression model used to compute the test statistic is reported in brackets. ${ }^{*}, * *$, and ${ }^{* * *}$ indicate significance at the 10 percent, 5 percent, and 1 percent levels. Standard errors are reported in parentheses.

nal interest rates argues for cointegration analysis of those variables to ascertain the EPRR's integration properties. When we prespecify a $(1,-1)^{\prime}$ cointegrating vector and apply unit root tests to the EPRR, we reject the unit root null at the 5 percent level using the ADF statistic and at the 1 percent level using the $M Z_{\alpha}$ statistic. The U.S. EPRR appears to be stationary.

To test the null hypothesis of no cointegration without prespecifying a cointegrating vector, Table 3 reports the AEG statistic, $M Z_{\alpha}$ statistic from Perron and Rodriguez (2001), and trace statistic from Johansen (1991). The AEG and trace statistics reject the null hypothesis of no cointegration at the 10 percent level, and the $M Z_{\alpha}$ statistic rejects the null at the 5 percent level. Table 3 also reports estimates of the cointegrating coefficients, $\theta_{0}$ and $\theta_{1}$. Neither the dynamic ordinary least squares (OLS) nor Johansen (1991) estimates of $\theta_{1}$ are significantly different from unity, indicating a stationary U.S. EPRR. The cointegrating vector is not estimated precisely enough to determine whether there is a tax effect.

Tables 2 and 3 provide evidence that the U.S. EPRR is stationary, although some of the rejections are marginal. Unit root and cointegration test results, however, are sensitive to the test proce- dure and sample period. Studies such as Mishkin (1992), Wallace and Warner (1993), and Crowder and Hoffman (1996) find evidence of a stationary U.S. EPRR, but Koustas and Serletis (1999) and Rapach and Weber (2004) generally do not. In contrast, per capita consumption growth is clearly stationary, as the $\mathrm{ADF}$ and $M Z_{\alpha}$ statistics in Table 2 both strongly reject the unit root null hypothesis for this variable. The fact that integration tests give mixed results for the EPRR's stationarity and clear-cut results for consumption growth highlights differences in the persistence properties of the two variables.

\section{Confidence Intervals for the Sum of the Autoregressive Coefficients}

The sum of the AR coefficients, $\rho$, in the AR representation of $i_{t}-\pi_{t+1}$ equals unity for an $I(1)$ process, while $\rho<1$ for an $I(0)$ process. It is inherently difficult, however, to distinguish an $I(1)$ process from a highly persistent $I(0)$ process, as the two types of processes can be observationally equivalent (Blough, 1992; Faust, 1996). ${ }^{12}$ To ana-

\footnotetext{
${ }^{12}$ In line with this, Crowder and Hoffman (1996) emphasize that impulse response analysis indicates that shocks have very persistent effects on the EPRR, although the U.S. EPRR appears to be $I(0)$.
} 


\section{Neely and Rapach}

lyze the theoretical implications of the time-series properties of the real interest rate, however, we want to determine a range of values for $\rho$ that are consistent with the data, not only whether $\rho$ is less than or equal to 1 . That is, a series with a $\rho$ value of 0.95 is highly persistent, even if it does not contain a unit root per se, and it is much more persistent than a series with a $\rho$ value of, say, 0.4.

To calculate the degree of persistence in the data-rather than simply trying to determine if the series is $I(0)$ or $I(1)$ - Rapach and Wohar (2004) compute 95 percent confidence intervals for $\rho$ using the Hansen (1999) grid-bootstrap and Romano and Wolf (2001) subsampling procedures. ${ }^{13}$ Using quarterly nominal long-term government bond yield and CPI inflation rate data for 13 industrialized countries for 1960-68, Rapach and Wohar (2004) report that the lower bounds of the 95 percent confidence interval for $\rho$ for the tax-adjusted EPRR are often greater than 0.90, while the upper bounds are almost all greater than unity. Similarly, Karanasos, Sekioua, and Zeng (2006) use a long span of monthly U.S. longterm government bond yield and CPI inflation data for 1876-2000 to compute a 95 percent confidence interval for the EPRR's $\rho$. Their computed interval, $(0.97,0.99)$, indicates that the U.S. EPRR is a highly persistent or near-unit-root process, even if it does not actually contain a unit root.

With the same U.S. data underlying the results in Tables 2 and 3, we use the Hansen (1999) grid-bootstrap and Romano and Wolf (2001) subsampling procedures to compute a 95 percent confidence interval for $\rho$ in the $i_{t}-\pi_{t+1}$ process. The grid-bootstrap and subsampling confidence intervals are $(0.77,0.97)$ and $(0.71,0.97)$, and the upper bounds are consistent with a highly persis tent process. In contrast, the grid-bootstrap and subsampling 95 percent confidence intervals or

\footnotetext{
${ }^{13}$ Andrews and Chen (1994) argue that the sum of the AR coefficients, $\rho$, characterizes the persistence in a series, as it is related to the cumulative impulse response function and the spectrum at zero frequency. While conventional asymptotic or bootstrap confidence intervals do not generate valid confidence intervals for nearly integrated processes (Basawa et al., 1991), Hansen (1999) and Romano and Wolf (2001) show that their procedures do generate confidence intervals for $\rho$ with correct first-order asymptotic coverage. Mikusheva (2007) shows, however, that while the Hansen (1999) grid-bootstrap procedure has correct asymptotical coverage, the Romano and Wolf (2001) subsampling procedure does not.
}

$\rho$ for per capita consumption growth are $(0.34$, $0.70)$ and $(0.37,0.64)$. The upper bounds of the confidence intervals for $\rho$ for consumption growth are less than the lower bounds of the confidence intervals for $\rho$ for the EPRR. This is another way to characterize the mismatch in the persistence properties of the EPRR and consumption growth.

\section{Testing for Fractional Integration}

Unit root and cointegration tests are designed to ascertain whether a series is $I(0)$ or $I(1)$, and the $I(0) / I(1)$ distinction implicitly restricts-perhaps inappropriately - the types of dynamic processes allowed. In response, some researchers test for fractional integration (Granger, 1980; Granger and Joyeux, 1980; Hosking, 1981) in the EARR and EPRR. A fractionally integrated series is denoted by $I(d), 0 \leq d \leq 1$. When $d=0$, the series is $I(0)$, and shocks die out at a geometric rate; when $d=1$, the series is $I(1)$, and shocks have permanent effects or "infinite memory." An intermediate case occurs when $0<d<1$ : The series is mean-reverting, as in the $I(0)$ case, but shocks now die out at a much slower hyperbolic (rather than geometric) rate. Series in which $0<d<1$ exhibit "long memory," mean-reverting behavior, and can be substantially more persistent than even a highly persistent $I(0)$ series.

A number of studies, including Lai (1997), Tsay (2000), Karanasos, Sekioua, and Zeng (2006), Sun and Phillips (2004), and Pipatchaipoom and Smallwood (2008), test for fractional integration in the U.S. EPRR or EARR. Using U.S. postwar monthly or quarterly U.S. data, Lai (1997), Tsay (2000), and Pipatchaipoom and Smallwood (2008) all present evidence of long-memory, meanreverting behavior, as estimates of $d$ for the U.S. EPRR or EARR typically range from 0.7 to 0.8 and are significantly above 0 and below 1 . Using a long span of annual U.S. data (1876-2000), Karanasos, Sekioua, and Zeng (2006) similarly find evidence of long-memory, mean-reverting behavior in the EPRR. Sun and Phillips (2004) develop a new bivariate econometric procedure that estimates the EARR's $d$ parameter in the 0.75 to 1.0 range for quarterly postwar U.S. data.

Overall, fractional integration tests indicate that the U.S. EPRR and EARR do not contain a 
unit root per se but are mean-reverting and very persistent. We confirm this by estimating $d$ for the EPRR using our sample of U.S. data for 1953:Q12007:Q2 with the Shimotsu (2008) semiparametric two-step feasible exact local Whittle estimator that allows for an unknown mean in the series. This estimator refines the Shimotsu and Phillips (2005) exact local Whittle estimator, and these authors show that such local Whittle estimators of $d$ have good properties in Monte Carlo experiments. The estimate of $d$ for the EPRR is 0.71 , with a 95 percent confidence interval of $(0.51,0.90)$, so we can reject the hypothesis that $d=0$ or $d=1$. This evidence of long-memory, mean-reverting behavior is consistent with the results from the literature discussed previously. The estimate of $d$ for per capita consumption growth is 0.15 with a standard error of 0.10 , so we cannot reject the hypothesis that $d=0$ at conventional significance levels. This is another manifestation of the discrepancy in persistence between the real interest rate and consumption growth.

\section{Testing for Threshold Dynamics and Nonlinear Cointegration}

The empirical literature on the real interest rate typically uses models that assume both the cointegrating relationship and short-run dynamics to be linear. ${ }^{14}$ Recently, researchers have begun to relax these linearity assumptions in favor of nonlinear cointegration or threshold dynamics, which allow for the cointegrating relationship or mean reversion to depend on the current values of the variables. For example, a threshold model might permit the EPRR to be approximately a random walk within \pm 2 percent of some long-run equilibrium value but to revert strongly to the \pm 2 percent bands when it wanders outside the bands. ${ }^{15}$

Million (2004) presents evidence that the U.S. EPRR adjusts in a nonlinear fashion to a long-run equilibrium level using a logistic smooth transi-

\footnotetext{
${ }^{14}$ Studies that allow for fractional integration or structural breaks also relax some linearity assumptions but in a different way than those reviewed in this subsection.

${ }^{15}$ The purchasing power parity literature often uses these threshold models (Sarno and Taylor, 2002).
}

tion autoregressive (LSTAR) model and monthly U.S. 3-month Treasury bill rate and CPI inflation rate data for 1951-99. The Lagrange multiplier test of Luukkonen, Saikkonen, and Teräsvirta (1988) rejects the null hypothesis of a linear dynamic adjustment process, and there is evidence of stronger (weaker) mean reversion in the EPRR for values of the EPRR below (above) a threshold level of 2.2 percent. Million (2004) notes that the weak mean reversion in the upper regime is consistent with the fact that the U.S. real interest rate was persistently high during much of the 1980s, and he observes that the Federal Reserve's priority on fighting inflation, following the stagflation of the 1970s, could explain this period of high real rates. In a vein similar to that of Million, Koustas and Lamarche (2008) estimate threeregime self-exciting threshold autoregressive (SETAR) models to characterize the monetary policy strategy of "opportunistic disinflation” (Blinder, 1994; Orphanides and Wilcox, 2002). Based on the nonlinear unit root test of Bec, Salem, and Carassco (2004) and Hansen (1996, 1997) linearity tests, Koustas and Lamarche (2008) conclude that the EPRR can be suitably modeled as a three-regime SETAR process in Canada, France, and Italy over the postwar period. ${ }^{16}$

Christopoulos and León-Ledesma (2007) examine quarterly U.S. 3-month Treasury bill rate and CPI inflation rate data for 1960-2004, permitting the cointegrating relationship itself to be nonlinear. More precisely, they allow the cointegrating coefficient $\left(\theta_{1}\right)$ to vary with the inflation rate by estimating logistic and smooth exponential transition regression (LSTR and ESTR) models. Christopoulos and León-Ledesma (2007) find significant evidence of nonlinear cointegration between the nominal interest rate and inflation rate using the Choi and Saikkonen (2005) test. Using estimation techniques from Saikkonen and Choi (2004), the authors conclude

\footnotetext{
${ }^{16}$ Maki (2003) uses the Breitung (2002) nonparametric procedure that allows for nonlinear adjustment dynamics to test for cointegration between the Japanese nominal interest rate and CPI inflation rate for 1972:01-2000:12. While Maki (2003) finds significant evidence of cointegration between the nominal interest rate and inflation rate using the Breitung (2002) test, he does not estimate the cointegrating vector, so it is not clear that the long-run equilibrium relationship is consistent with a stationary EPRR.
} 
that the ESTR model fits best over the full sample (1960:Q1-2004:Q4) and the first subsample (1960:Q1-1978:Q1), whereas the LSTR model fits best over the second subsample (1979:Q12004:Q4). The estimated ESTR model for 1960:Q11978:Q1 is not consistent with a stationary real EPRR for any inflation rate, and the estimated LSTR model for 1979:Q1-2004:Q4 is consistent with a stationary EPRR only when the inflation rate moves above approximately 3 percent.

In summary, recently developed econometric procedures provide some evidence of threshold behavior or nonlinear cointegration in the EPRR in certain industrialized countries. In some cases, the threshold models accord well with our intuition about changes in central bank policies. Although evidence of threshold behavior in real interest rates is potentially interesting, the models do not obviate the persistence in real interest rates, as there are still regimes where the real interest rate behaves very much like a unit root process.

\section{TESTING FOR REGIME SWITCHING AND STRUCTURL BREAKS IN REAL INTEREST RATES}

Building on the work of Huizinga and Mishkin (1986), another strand of the empirical literature tests for structural breaks in real interest rates. Accounting for such breaks can substantially reduce the persistence within the regimes defined by those breaks (Perron, 1989). Similarly, failing to account for structural breaks can produce spurious evidence of fractional integration (Jouini and Nouira, 2006).

Using quarterly U.S. 3-month Treasury bill rate and CPI inflation rate data for 1961-86, Garcia and Perron (1996) use Hamilton's (1989) Markovswitching approach to test for regime shifts in the U.S. EPRR. Specifically, they allow the unconditional mean of an AR(2) process to follow a threestate Markov process. The three estimated states correspond to high, middle, and low regimes with means of approximately 5.5 percent, 1.4 percent, and -1.8 percent, respectively. The filtered probability estimates show that the EPRR was likely in the middle regime from 1961-73, the low regime from 1973-81, and the high regime from 1981-86.
There is very little persistence within each regime, as the estimated AR coefficients $\left(\rho_{1}\right.$ and $\rho_{2}$ in equation (A1)) are near 0 within regimes. Overall, Garcia and Perron (1996) argue that the U.S. real interest rate occasionally experiences sizable shifts in its mean value, while the real interest rate is close to constant within the regimes.

Applications of Markov-switching models typically assume that the model is ergodic, so the current state will eventually cycle back to any possible state. Structural breaks have some similar properties to Markov-switching regimes, but they are not ergodic - they do not necessarily tend to revert to previous conditions. Because real interest rates in Garcia and Perron (1996) exhibit no obvious tendency to return to previous states, structural breaks might be considered more appropriate for modeling real interest rate changes than Markov switching. Bai and Perron (1998) develop a powerful methodology for testing for multiple structural breaks in a regression model, and Caporale and Grier (2000) and Bai and Perron (2003) apply this methodology to the mean of the U.S. EPRR. Both studies use quarterly U.S. short-term nominal interest rate and CPI inflation rate data for 1961-86, and the estimated break dates are very similar: 1967:Q1, 1972:Q4, and 1980:Q2 in Caporale and Grier (2000) and 1966:Q4, 1972:Q3, and 1980:Q3 in Bai and Perron (2003). The breaks correspond to a decrease in the mean EPRR in 1966/1967, a further decrease in 1972, and a sharp increase in 1980. Caporale and Grier argue that changes in political regimes-party control of the presidency and Senate-produce these regime changes.

Rapach and Wohar (2005) extend the work of Caporale and Grier (2000) and Bai and Perron (2003) by applying the Bai and Perron (1998) methodology to the EPRR in 13 industrialized countries using tax-adjusted nominal long-term government bond yield and CPI inflation rate data for 1960-98. They find significant evidence of structural breaks in the mean of the EPRR in each of the 13 countries. Rapach and Wohar (2005) also find that breaks in the mean inflation rate often coincide with breaks in the mean EPRR for each country's data. Furthermore, increases (decreases) in the mean inflation rate are almost always associated with decreases (increases) in the mean EPRR. 


\section{Table 4}

\section{Bai and Perron (1988) Test Statistics and Estimation Results for the U.S. ex post Real Interest Rate (1953:Q1-2007:Q2)}

\begin{tabular}{llcc} 
Test statistic & \multicolumn{1}{c}{ Regime } & $\begin{array}{c}\text { Estimated ex post } \\
\text { real interest rate mean }\end{array}$ \\
\hline$U D_{\max }$ & $14.84^{* * *}$ & $1953: \mathrm{Q} 1-1972: \mathrm{Q} 3[1969: \mathrm{Q} 2,1973: \mathrm{Q} 4]$ & $1.22^{* * *}(0.17)$ \\
$W D_{\max }(5 \%)$ & $27.06^{* *}$ & $1972: \mathrm{Q} 4-1980: \mathrm{Q} 3[1979: \mathrm{Q} 1,1980: \mathrm{Q} 4]$ & $-0.55(0.38)$ \\
$F(1 \mid 0)$ & $12.92^{* * *}$ & $1980: \mathrm{Q} 4-1989: \mathrm{Q} 3[1984: \mathrm{Q} 3-1994: \mathrm{Q} 2]$ & $4.58^{* * *}(0.71)$ \\
$F(2 \mid 1)$ & $17.89^{* * *}$ & $1989: \mathrm{Q} 4-2007: \mathrm{Q} 2$ & $1.82^{* * *}(0.52)$ \\
$F(3 \mid 2)$ & $17.89^{* * *}$ & & \\
$F(4 \mid 3)$ & $10.37^{*}$ & & \\
$F(5 \mid 4)$ & 10.37 & &
\end{tabular}

NOTE: ${ }^{*},{ }^{* *}$, and ${ }^{* * *}$ indicate significance at the 10 percent, 5 percent, and 1 percent levels. The bracketed dates in the Regime column denote a 90 percent confidence interval for the end of the regime. Numbers in parentheses in the last column denote standard errors for the estimated mean.

This finding is consistent with the hypothesis that monetary easing increases inflation and generates a persistent decline in the real interest rate.

In a comment on Rapach and Wohar (2005), Caporale and Grier (2005) examine whether political regime changes affect the mean U.S. EPRR, after controlling for the effects of regime changes in the inflation rate. Caporale and Grier (2005) find that political regime changes associated with changes in the party of the president or control of Congress do not affect the mean EPRR after controlling for inflation. However, the appointments of Federal Reserve Chairmen Paul Volcker in 1979 and Alan Greenspan in 1987 are associated with shifts in the mean EPRR even after controlling for changes in the mean inflation rate.

The previous papers test for structural breaks under the assumption of stationary within-regime behavior. In the spirit of Perron (1989), a number of studies test whether the real interest rate is $I(0)$ after allowing for deterministic shifts in the mean real rate. Extending the methodology of Perron and Vogelsang (1992), Clemente, Montañés, and Reyes (1998) test the unit root null hypothesis for the U.K. and U.S. EPRR using quarterly long-term government bond yield and CPI inflation rate data for 1980-95, allowing for two breaks in the mean of the EPRR. They find that the EPRR in the United Kingdom and United States is an $I(0)$ process around an unconditional mean with two breaks. Using monthly U.S. 1-year Treasury bill rate data for 1978-2002 and expected inflation data from the University of Michigan's Survey of Consumers, Lai (2004) finds that the EARR is an $I(0)$ process with a shift in its unconditional mean in the early 1980s. Lai (2008) extends Lai (2004) by allowing for a mean shift in quarterly real interest rates for eight industrialized countries and eight developing countries and finds widespread support for a stationary EPRR after allowing for a break in the unconditional mean.

To further illustrate the prevalence of structural breaks, we use the Bai and Perron (1998) methodology to test for such instability in the unconditional mean of the U.S. EPRR for 1953:Q12007:Q2. ${ }^{17}$ Table 4 reports the results. The procedure finds three changes in the mean that occur at 1972:Q3, 1980:Q3, and 1989:Q3 and are similar to those previously identified for the United States. ${ }^{18}$ The breaks are associated with substan-

\footnotetext{
${ }^{17}$ We focus on the Bai and Perron (1998) methodology in analyzing mean real interest rate shifts in updated U.S. data. It would be interesting in future research to consider regime-switching models and recently developed structural break tests such as described by Elliott and Müller (2006).

${ }^{18}$ Rapach and Wohar (2005) discuss how the statistics reported in Table 4 imply that there are three significant breaks in the unconditional mean.
} 
Figure 2

\section{U.S. Ex Post Real Interest Rate and Regime-Specific Means, 1953:Q1-2007:Q2}

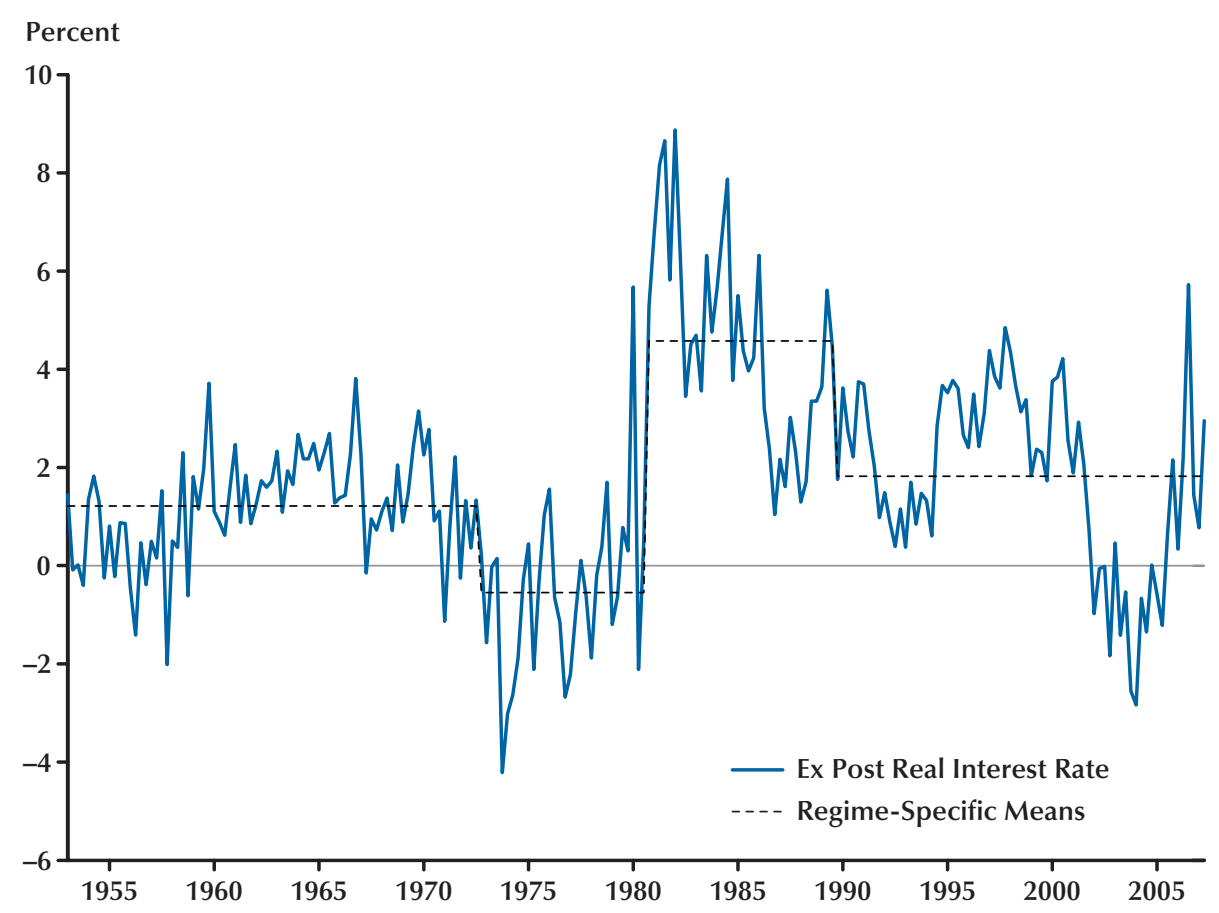

NOTE: The figure plots the U.S. ex post real interest rate and means for the regimes defined by the structural breaks estimated using the Bai and Perron (1998) methodology.

tial changes in the average annualized real interest rate in the different regimes. The average real rate is 1.22 percent for 1953:Q1-1972:Q3, is not significantly different from zero for 1972:Q41980:Q3, increases to 4.58 percent for 1980:Q41989:Q3, and falls to 1.82 percent for 1989:Q42007:Q2. Figure 2 depicts the EPRR and the mean for each of the four regimes defined by the three breaks. ${ }^{19}$ In contrast to this evidence for breaks in the real rate, the Bai and Perron (1998) methodology fails to discover significant evidence of structural breaks in the mean of per capita consumption growth. (We omit complete results for brevity.)

\footnotetext{
${ }^{19}$ The test results of Bai and Perron (1998) for structural breaks in the mean EPRR do not appear sensitive to whether the tax-adjusted or tax-unadjusted EPRR is used (Rapach and Wohar, 2005). Neither do estimates of the sum of the AR coefficients nor tests for fractional integration hinge critically on whether the EPRR is tax adjusted.
}

In interpreting structural break results, we emphasize that such breaks only reduce withinregime or local persistence in real interest rates. The existence of breaks still implies a high degree of global persistence, and the breaks themselves require an economic explanation.

\section{THEORETICAL IMPLICATIONS AND A MONETARY EXPLANATION OF PERSISTENCE}

This section considers what types of shocks are most likely to produce the persistence in the U.S. real interest rate. The empirical literature devotes relatively little attention to this important issue. We argue that monetary shocks likely drive the persistence in the U.S. real interest rate. 
Before discussing potential sources of real interest rate persistence, we briefly make the case that the U.S. real interest rate is ultimately mean-reverting. As we emphasize, unit root and cointegration tests have difficulty distinguishing unit root processes from persistent but stationary alternatives. Nevertheless, unit root and cointegration tests with good size and power, applied to updated data, provide evidence that the U.S. real interest rate is an $I(0)$-and thus mean-revertingprocess (see Table 2) ${ }^{20}$ Tests for fractional integration nest the $I(0) / I(1)$ alternatives, and they concur that the U.S. real interest rate is a mean-reverting process. Using an updated sample, we confirm the findings of Lai (1997), Tsay (2000), Pipatchaipoom and Smallwood (2008), and Karanasos, Sekioua, and Zeng (2006) that demonstrate long-memory, mean-reverting behavior in the U.S. real interest rate. Our updated sample also provides evidence of structural breaks in the U.S. real interest rate. Curiously, the regime-specific mean breaks for the EPRR largely cancel each other in the long run (see Table 4): The estimated mean real rate in 2007 is close to that estimated for $1953 .{ }^{21}$ We speculate that although structural breaks appear to describe the data better than a constant, linear data generating process, these breaks appear to exhibit a certain type of mean-reverting behavior. With sufficient data-much more than we have now-one could presumably model this meanreversion in regimes.

These facts lead us to tentatively claim that the U.S. real interest rate is best viewed as a very persistent but ultimately mean-reverting process. We emphasize the tentative nature of this claim, and we consider careful econometric testing of this proposition to be an important area for future research. Even if real interest rates ultimately mean-revert, they are clearly very persistent.

Recall the underlying motivation for learning about real interest rate persistence: In a simple

\footnotetext{
${ }^{20}$ Recall, however, that unit root and cointegration tests are sensitive to the particular sample used.

${ }^{21}$ One might wonder if the observed mean-reversion in structural breaks contradicts our contention that the breaks should not be modeled as a Markov process because they are not ergodic. We do not think, however, that observing one state twice and two states once provides sufficient information for a Markov process.
}

endowment economy, the real interest rate should have the same persistence properties as consumption growth. In fact, however, real rates are much more persistent than consumption growth. Permanent technology growth shocks can create a nonstationary real rate but affect consumption growth in the same way, so they cannot account for the mismatch in persistence. More complex equilibrium growth models potentially explain this persistence mismatch through changing fiscal and monetary policy, as well as transient technology growth shocks. We consider fiscal, monetary, and transient technology shocks as potential causes of persistent fluctuations in the U.S. real interest rate.

Figures 1 and 2 reveal two episodes of pronounced and prolonged changes in the U.S. EPRR: the protracted decrease in the EPRR in the 1970s and subsequent sharp increase in the 1980s. Fiscal shocks appear to be an unlikely explanation for the large decline in real rates from 1972-79. The U.S. did not undertake the sort of contractionary fiscal policy that would be necessary for such a fall in real rates. ${ }^{22}$ In fact, fiscal policy in the 1970 s largely tended toward modest deficits. Given the substantial budget deficits beginning in 1981, expansionary fiscal shocks are a more plausible candidate for the increase in real rates at this time.

Monetary shocks appear to fit well with the overall pattern in the real interest rate, including the multiyear decline in the real rate during the 1970s, the very sharp 1980 increase, and subsequent gradual decline during the "Great Disinflation." One interpretation of the "Great Inflation" that began in the late 1960s and lasted throughout the 1970s is that the Federal Reserve pursued an expansionary monetary policy-either inadvertently or to reduce the unemployment rate to unsustainable levels-and this persistently reduced the real interest rate (Delong, 1997; Barsky and Kilian, 2002; Meltzer, 2005; Romer, 2005). After Paul Volcker's appointment as Chairman, the Federal Reserve sharply raised short-term nominal interest rates to reduce inflation from its early 1980 peak of nearly 12 percent, and this

\footnotetext{
${ }^{22}$ The recent analyses by Romer and Romer (2008) and Ramey (2008) indicate that the U.S. economy did not experience sizable contractionary fiscal policy shocks during the 1970s.
} 
Figure 3

\section{Romer and Romer (2004) Measure of Monetary Policy Shocks, 1969:Q1-1996:Q4}

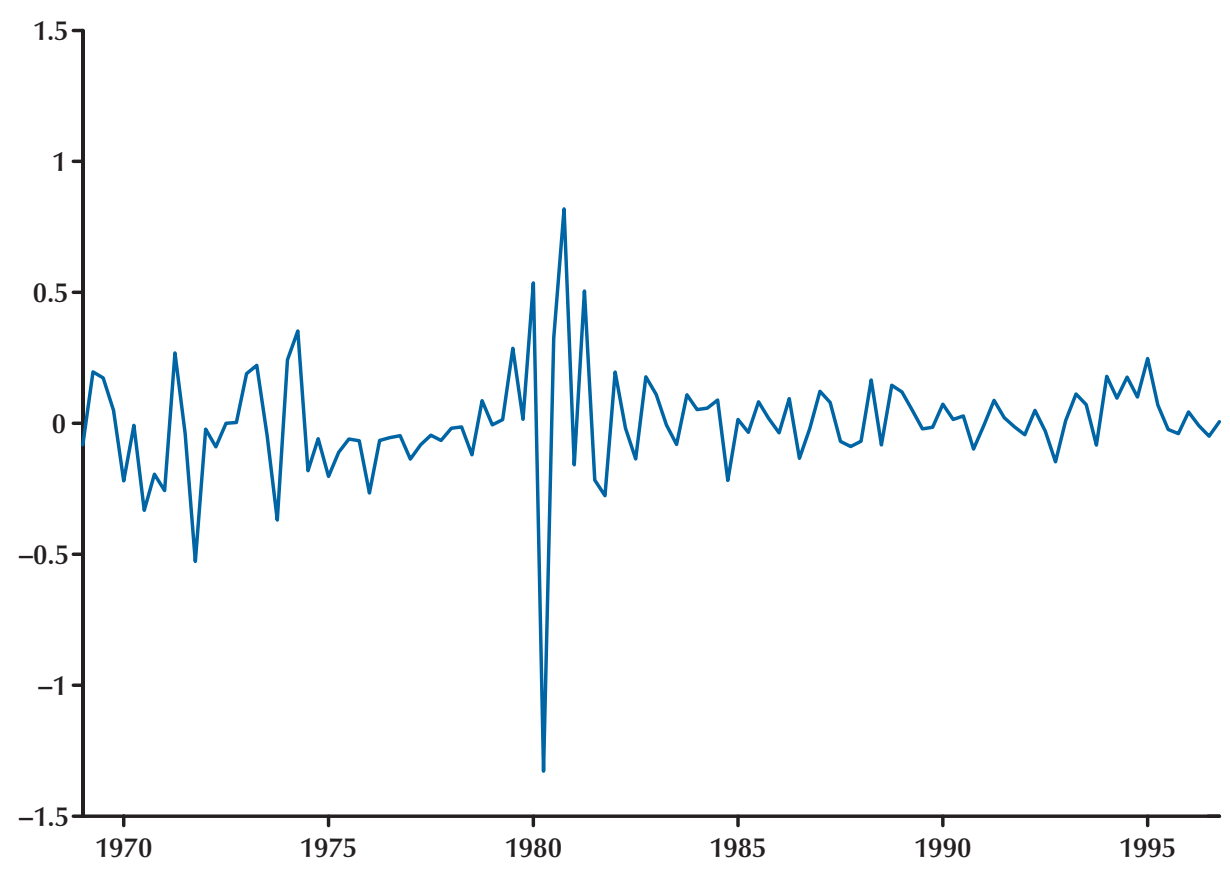

NOTE: A positive (negative) value corresponds to a contractionary (expansionary) monetary policy shock.

produced a sharp and prolonged increase in the real interest rate. The structural breaks manifest these pronounced swings: The mean EPRR falls from 1.22 percent in 1972:Q3 to essentially zero and then rises to 4.58 percent beginning in 1980:Q4 (see Table 4). Furthermore, Rapach and Wohar (2005) report evidence of breaks in the mean U.S. inflation rate in 1973:Q1 and 1982:Q1 that increase and decrease the average inflation rate. The timing and direction of the breaks are consistent with a monetary explanation that also accounts for the mismatch in persistence between the real interest rate and consumption growth. In each case, negative (positive) breaks to the real rate of interest coincide with positive (negative) breaks in the mean rate of inflation. The data are in line with the hypothesis that central banks change monetary policy and inflation through persistent effects on the real rate of interest.

Turning to technology shocks, the paucity of independent data on technology shocks makes it difficult to correlate such changes with real interest rates. In addition, researchers have traditionally viewed technology growth as reasonably stable. One might think that other sorts of supply shocks, such as oil price increases, might influence the real rate, and they surely do to some degree; Barro and Sala-i-Martin (1990) and Caporale and Grier (2000), for example, consider this possibility. It is unlikely, however, that oil price shocks alone can account for the pronounced swings in the U.S. real interest rate: Why would rising oil prices in 1973 reduce the real interest rates but rising oil prices in 1979 dramatically raise the real rate? ${ }^{23}$

While we interpret the timing of major swings in the U.S. real rate to strongly suggest a monetary explanation, we ultimately need to estimate

\footnotetext{
${ }^{23}$ Furthermore, Barsky and Kilian (2002) argue that the timing of increases in U.S. inflation in the early 1970s is more consistent with a monetary rather than an oil price shock explanation.
} 


\section{Figure 4}

\section{U.S. Ex Post Real Interest Rate Response to a Contractionary Romer and Romer (2004) Monetary Policy Shock}

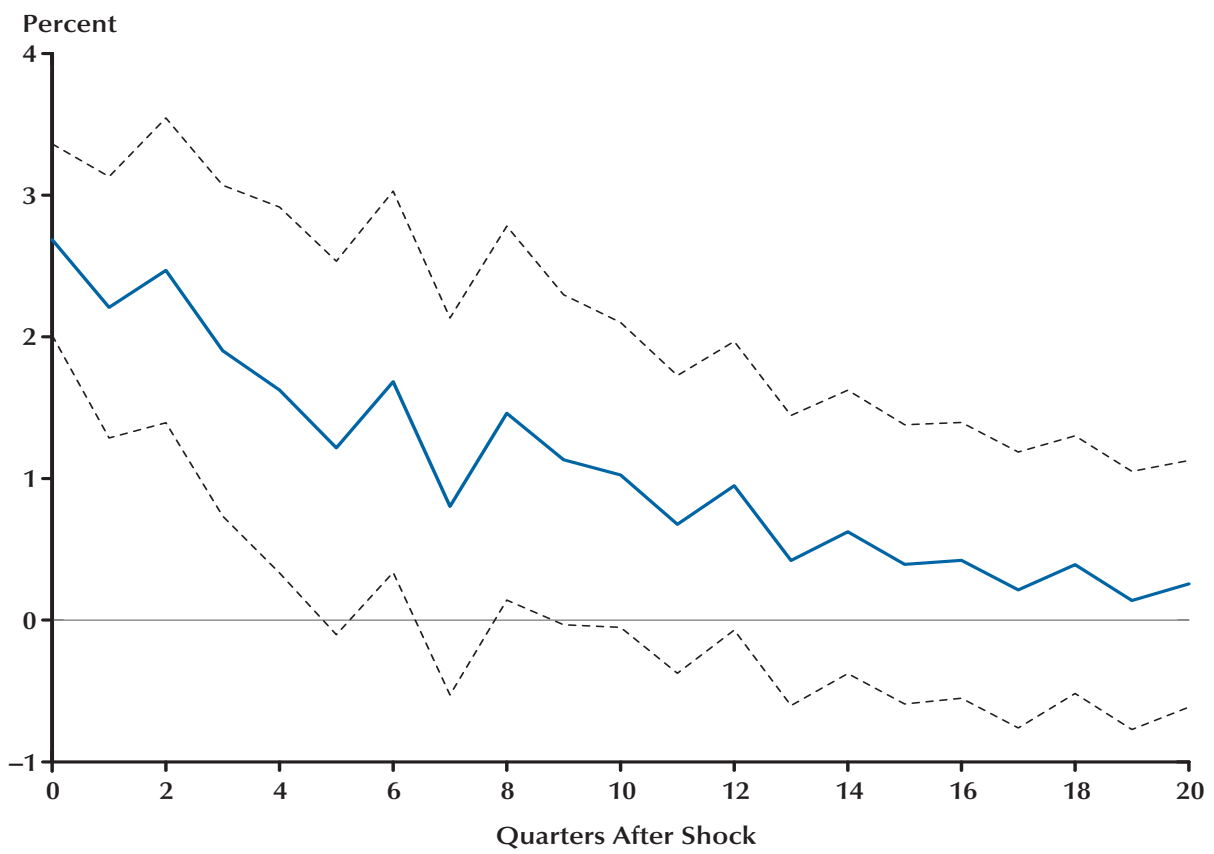

NOTE: The response is based on an autoregressive distributed lag model estimated for 1969:Q1-1996:Q4. Dashed lines delineate two-standard-error bands. The response is to a shock of size 0.5 .

structural models to analyze the relative importance of various shocks. Galí (1992) is one of the few studies providing evidence on the economic sources of real interest rate persistence. His SVAR model finds that an expansionary money supply shock leads to a very persistent decline in the real interest rate, and money supply shocks account for nearly 90 percent of the variance in the real rate at the one-quarter horizon and still account for around 60 percent of the variance at the 20quarter horizon. Galís (1992) evidence is consistent with our monetary explanation of real interest rate persistence. ${ }^{24}$

We present tentative additional evidence in support of a monetary explanation of real interest

\footnotetext{
${ }^{24}$ King and Watson (1997) and Rapach (2003) use SVAR frameworks to estimate the long-run effects of exogenous changes in inflation on the real interest rate. Both studies find evidence that an exogenous increase in the steady-state inflation rate decreases the steady-state real interest rate.
}

rate persistence based on the new measure of monetary shocks developed by Romer and Romer (2004). They cull through quantitative and narrative Federal Reserve records to compute a monetary policy shock series for 1969-96 that is independent of systematic responses to anticipated economic conditions. Figure 3 plots the Romer and Romer (2004) monetary policy shocks series, where expansionary (i.e., negative) shocks in the late 1960s and early 1970s and large contractionary (i.e., positive) shocks in the late 1970s and early 1980s appear to match well with the decline in the U.S. real interest rate in the 1970s and subsequent sharp increase around 1980.

Romer and Romer (2004) estimate autoregressive distributed lag (ARDL) models to examine the effects of a monetary policy shock on real output and the price level. They find that a contractionary shock creates persistent and sizable 


\section{Neely and Rapach}

declines in both real output and the price level. In similar fashion, we estimate an ARDL model via OLS to measure the effects of a monetary policy shock on the real interest rate. The ARDL model takes the form,

$$
r_{t}^{e p}=a_{0}+\sum_{j=1}^{8} a_{j} r_{t-j}^{e p}+\sum_{j=0}^{8} b_{j} S_{t-j}+u_{t},
$$

where $r_{t}^{e p}$ is the EPRR and $S_{t}$ is the Romer and Romer measure of monetary policy shocks.

Figure 4 illustrates the response of the EPRR to a monetary policy shock of size 0.5 , which is comparable to some of the contractionary shocks experienced in the late 1970s and early 1980s (see Figure 3). Romer and Romer's (2004) Monte Carlo methods provide the two-standard-error bands. A contractionary monetary policy shock produces a statistically and economically significant increase in the U.S. EPRR, which remains statistically significant after approximately two years. Note that the response in Figure 4 is nearly identical to the response of $r_{t}^{e p}$ to a shock to $S_{t}$ obtained from a bivariate VAR(8) model that orders $S_{t}$ first in a Cholesky decomposition. Together, Figures 3 and 4 show that expansionary (contractionary) monetary policy shocks can account for the pronounced and prolonged decrease (increase) in the U.S. real interest rate in the 1970s (early 1980s). We emphasize that this evidence is suggestive. Of course, structural identification is a thorny issue, and more research is needed to determine the veracity of the monetary explanation for U.S. real interest rate persistence.

\section{CONCLUSION}

Rose's (1988) seminal study spurred a sizable empirical literature that examines the time-series properties of real interest rates. Our survey details the evidence that real interest rates are highly persistent. This persistence manifests itself in the following ways:

- Under the assumption of a constant data generating process, many studies indicate that real interest rates contain a unit root. While econometric problems prevent a dispositive resolution of this question, real interest rates display behavior that is very persistent, close to a unit root.

- Estimated 95 percent confidence intervals for the sum of the AR coefficients from the literature have upper bounds that are greater than or very near unity.

- Real interest rates appear to display longmemory behavior; shocks are very longlived, but the real interest rate is estimated to be ultimately mean-reverting.

- Studies allowing for nonlinear dynamics in real interest rates identify regimes where the real interest behaves like a unit root process.

- Structural breaks in unconditional means characterize real interest rates. Although the breaks reduce within-regime persistence, the real interest rate remains highly persistent because the regimes have different means.

Although researchers have used a variety of econometric models to analyze the time-series properties of real interest rates, relatively little work has been done to discriminate among these sundry models. Model selection could tell us, for example, whether we should think of persistent changes in real interest rates in terms of changes in the steady-state real rate-which are consistent with unit root behavior-or long-lived shocks that eventually decay to a stable steady-state real rate-which are consistent with mean-reverting behavior. While model selection raises challenging econometric (and philosophical) issues, outof-sample forecasting exercises and analysis of posterior model probabilities in a Bayesian context might identify the best way to model real interest rate persistence.

Finally, structural analysis is necessary to identify the sources of the persistence in real interest rates. Theoretical models suggest that a variety of shocks can induce real rate persistence, including preference, technology growth, fiscal, and monetary shocks. We suggest a tentative monetary explanation of U.S. real interest rate persistence based on timing, lack of persistence in consumption growth, and large and persistent 
real interest rate responses to a Romer and Romer (2004) monetary policy shock. The literature would greatly benefit from further analysis of the relative importance of different types of shocks in explaining real interest rate persistence.

\section{REFERENCES}

Andolfatto, David; Hendry, Scott and Moran, Kevin. “Are Inflation Expectations Rational?" Journal of Monetary Economics, March 2008, 55(2), pp. 406-22.

Andrews, Donald W.K. and Chen, Hong-Yuan. "Approximately Median-Unbiased Estimation of Autoregressive Models." Journal of Business and Economic Statistics, April 1994, 12(2), pp. 187-204.

Antoncic, Madelyn. "High and Volatile Real Interest Rates: Where Does the Fed Fit In?" Journal of Money, Credit, and Banking, February 1986, 18(1), pp. 18-27.

Atkeson, Andrew and Ohanian, Lee E. "Are Phillips Curves Useful for Forecasting Inflation?” Federal Reserve Bank of Minneapolis Quarterly Review, Winter 2001, 25(1), pp. 2-11.

Bai, Jushan and Perron, Pierre. "Estimating and Testing Linear Models with Multiple Structural Changes.” Econometrica, 1998, 66(1), pp. 47-78.

Bai, Jushan and Perron, Pierre. "Computation and Analysis of Multiple Structural Change Models." Journal of Applied Econometrics, January 2003, 18(1), pp. 1-22.

Barro, Robert J. and Sala-i-Martin, Xavier. "World Real Interest Rates," in Olivier J. Blanchard and Stanley Fischer, eds., NBER Macroeconomics Annual 1990. Cambridge, MA: MIT Press, 1990, pp. 15-61.

Barro, Robert J. and Sala-i-Martin, Xavier. Economic Growth. Second Edition. Cambridge, MA: MIT Press, 2003.

Barsky, Robert B. and Kilian, Lutz. "Do We Really Know that Oil Caused the Great Stagflation? A Monetary Alternative," in Ben S. Bernanke and
Kenneth S. Rogoff, eds., NBER Macroeconomics Annual 2001. Cambridge, MA: MIT Press, 2002, pp. 137-83.

Basawa, I.V.; Mallik, A.K.; McCormick, W.P.; Reeves, J.H. and Taylor, R.L. "Bootstrapping Unstable FirstOrder Autoregressive Processes." Annals of Statistics, June 1991, 19(2), pp. 1098-101.

Baxter, Marianne and King, Robert G. "Fiscal Policy in General Equilibrium.” American Economic Review, June 1993, 83(3), pp. 315-34.

Bec, Frédérique; Ben Salem, Mélika and Carassco, Marine. "Tests for Unit-Root versus Threshold Specification with an Application to the Purchasing Power Parity Relationship." Journal of Business and Economic Statistics, October 2004, 22(4), pp. 382-95.

Bierens, Herman J. "Nonparametric Nonlinear Cotrending Analysis, with an Application to Interest and Inflation in the United States." Journal of Business and Economic Statistics, July 2000, 18(3), pp. 323-37.

Blanchard, Olivier J. "Debt, Deficits, and Finite Horizons." Journal of Political Economy, April 1985, 93(2), pp. 223-47.

Blanchard, Olivier J. and Fischer, Stanley. Lectures on Macroeconomics. Cambridge, MA: MIT Press, 1989.

Blinder, Alan S. "Opening Statement of Alan S. Blinder at Confirmation Hearing Before the U.S. Senate Committee on Banking, Housing, and Urban Affairs." Unpublished manuscript, Board of Governors of the Federal Reserve System, May 1994.

Blough, Stephen R. "The Relationship Between Power and Level for Generic Unit Root Tests in Finite Samples." Journal of Applied Econometrics, July-September 1992, 7(3), pp. 295-308.

Breeden, Douglas T. “An Intertemporal Asset Pricing Model with Stochastic Consumption and Investment Opportunities." Journal of Financial Economics, September 1979, 7(3), pp. 265-96. 


\section{Neely and Rapach}

Breitung, Jörg. "Nonparametric Tests for Unit Roots and Cointegration.” Journal of Econometrics, December 2002, 108(2), pp. 343-63.

Bullard, James B. and Russell, Steven H. "How Costly Is Sustained Low Inflation for the U.S. Economy?" Federal Reserve Bank of St. Louis Review, May/June 2004, 86(3), pp. 35-67; research.stlouisfed.org/publications/review/04/05/ Bullard.pdf.

Caporale, Tony and Grier, Kevin B. "Political Regime Change and the Real Interest Rate." Journal of Money, Credit, and Banking, August 2000, 32(3), pp. 320-34.

Caporale, Tony and Grier, Kevin B. "Inflation, Presidents, Fed Chairs, and Regime Changes in the U.S. Real Interest Rate." Journal of Money, Credit, and Banking, December 2005, 37(6), pp. 1153-63.

Carlson, John A. "Short-Term Interest Rates as Predictors of Inflation: Comment." American Economic Review, June 1977, 67(3), pp. 469-75.

Cass, David. "Optimum Growth in an Aggregate Model of Capital Accumulation." Review of Economic Studies, July 1965, 32(3), pp. 233-40.

Christopoulos, Dimitris K. and León-Ledesma, Miguel A. "A Long-Run Nonlinear Approach to the Fisher Effect.” Journal of Money, Credit, and Banking, March-April 2007, 39(2-3), pp. 543-59.

Clark, Gregory. A Farewell to Alms: A Brief History of the Economic World. Princeton, NJ: Princeton University Press, 2007.

Choi, In and Saikkonen, Pentti. "Test for Nonlinear Cointegration.” Unpublished manuscript, Hong Kong University of Science and Technology and Helsinki University, 2005.

Clemente, Jesús; Montañés, Antonio and Reyes, Marcelo. "Testing for a Unit Root in Variables with a Double Change in Mean." Economics Letters, May 1998, 59(2), pp. 175-82.

Crowder, William J. and Hoffman, Dennis L. "The Long-Run Relationship Between Nominal Interest
Rates and Inflation: The Fisher Equation Revisited.” Journal of Money, Credit, and Banking, February 1996, 28(1), pp. 102-18.

Crowder, William J. and Wohar, Mark E. “Are Tax Effects Important in the Long-Run Fisher Relationship? Evidence from the Municipal Bond Market.” Journal of Finance, February 1999, 54(1), pp. 307-17.

Darby, Michael R. "The Financial and Tax Effects of Monetary Policy on Interest Rates.” Economic Inquiry, June 1975, 13(2), pp. 266-76.

DeJong, David N.; Nankervis, John C.; Savin, N.E. and Whiteman, Charles H. "The Power Problems of Unit Root Tests in Time Series with Autoregressive Errors.” Journal of Econometrics, 1992, 53(1-3), pp. 323-43.

DeLong, J. Bradford. “America’s Peacetime Inflation: The 1970s," in Christina D. Romer and David H. Romer, eds., Reducing Inflation. Chicago: University of Chicago Press, 1997, pp. 247-76.

Diamond, Peter A. "National Debt in a Neoclassical Growth Model.” American Economic Review, December 1965, 55(5), pp. 1126-50.

Dickey, David A. and Fuller, Wayne A. "Distribution of the Estimators for Autoregressive Time Series with a Unit Root.” Journal of the American Statistical Association, June 1979, 74(366), pp. 427-31.

Dotsey, Michael; Lantz, Carl and Scholl, Brian. "The Behavior of the Real Rate of Interest." Journal of Money, Credit, and Banking, February 2003, 35(1), pp. 91-110.

Elliott, Graham and Müller, Ulrich. "Efficient Tests for General Persistent Time Variation in Regression Coefficients." Review of Economic Studies, October 2006, 73(4), pp. 907-40.

Elliott, Graham; Rothenberg, Thomas J. and Stock, James H. "Efficient Tests for an Autoregressive Unit Root.” Econometrica, July 1996, 64(4), pp. 813-36. 
Engle, Robert F. and Granger, Clive W.J. "Co-integration and Error Correction: Representation, Estimation, and Testing." Econometrica, March 1987, 55(2), pp. 251-76.

Engsted, Tom. "Does the Long-Term Interest Rate Predict Future Inflation? A Multi-Country Analysis." Review of Economics and Statistics, February 1995, 77(1), pp. 42-54.

Espinosa-Vega, Marco A. and Russell, Steven H. "Can Higher Inflation Reduce Real Interest Rates in the Long Run?" Canadian Journal of Economics, February 1998a, 31(1), pp. 92-103.

Espinosa-Vega, Marco A. and Russell, Steven H. "The Long-Run Real Effects of Monetary Policy: Keynesian Predictions from a Neoclassical Model.” Working Paper No. 98-6, Federal Reserve Bank of Atlanta, April 1998b; www.frbatlanta.org/filelegacydocs/wp9806.pdf.

Evans, Martin D.D. and Lewis, Karen K. "Do Expected Shifts in Inflation Affect Estimates of the Long-Run Fisher Relation?" Journal of Finance, March 1995, 50(1), pp. 225-53.

Fama, Eugene F. "Short-Term Interest Rates as Predictors of Inflation." American Economic Review, June 1975, 65(3), pp. 269-82.

Fama, Eugene F. "Inflation Uncertainty and Expected Returns on Treasury Bills." Journal of Political Economy, June 1976, 84(3), pp. 427-48.

Faust, Jon. "Near Observational Equivalence and Theoretical Size Problems with Unit Root Tests." Econometric Theory, October 1996, 12(4), pp. 724-31.

Galí, Jordi. "How Well Does the IS-LM Model Fit Postwar U.S. Data?" Quarterly Journal of Economics, May 1992, 107(2), pp. 709-38.

Garbade, Kenneth and Wachtel, Paul. "Time Variation in the Relationship between Inflation and Interest Rates." Journal of Monetary Economics, November 1978, 4(4), pp. 755-65.

Garcia, René and Perron, Pierre. "An Analysis of the Real Interest Rate Under Regime Shifts.” Review of
Economics and Statistics, February 1996, 78(1), pp. 111-25.

Granger, Clive W.J. "Long Memory Relationships and the Aggregation of Dynamic Models." Journal of Econometrics, October 1980, 14(2), pp. 227-38.

Granger, Clive W.J. and Joyeux, Roselyne. "An Introduction to Long-Memory Time Series Models and Fractional Differencing." Journal of Time Series Analysis, 1980, 1, pp. 15-39.

Hamilton, James D. "A New Approach to the Economic Analysis of Nonstationary Time Series and the Business Cycle.” Econometrica, March 1989, 57(2), pp. 357-84.

Hamilton, James D. Time Series Analysis. Princeton, NJ: Princeton University Press, 1994.

Hansen, Bruce E. "Inference when a Nuisance Parameter Is Not Identified Under the Null Hypothesis.” Econometrica, March 1996, 64(2), pp. 413-30.

Hansen, Bruce E. "Inference in TAR Models.” Studies in Nonlinear Dynamics and Econometrics, 1997, 2(1), pp. 1-14.

Hansen, Bruce E. "The Grid Bootstrap and the Autoregressive Model." Review of Economics and Statistics, November 1999, 81(4), pp. 594-607.

Hansen, Lars P. and Singleton, Kenneth J. "Generalized Instrumental Variables Estimation of Nonlinear Rational Expectations Models." Econometrica, September 1982, 50(5), pp. 1269-86.

Hansen, Lars P. and Singleton, Kenneth J. "Stochastic Consumption, Risk Aversion, and the Temporal Behavior of Asset Returns." Journal of Political Economy, April 1983, 91(2), pp. 249-65.

Hess, Patrick J. and Bicksler, James L. "Capital Asset Prices Versus Time Series Models as Predictors of Inflation: The Expected Real Rate of Interest and Market Efficiency." Journal of Financial Economics, December 1975, 2(4), pp. 341-60.

Hosking, J.R.M. "Fractional Differencing." Biometrika, April 1981, 68(1), pp. 165-76. 


\section{Neely and Rapach}

Huizinga, John and Mishkin, Frederic S. "Monetary Policy Regime Shifts and the Unusual Behavior of Real Interest Rates." Carnegie-Rochester Conference Series on Public Policy, 1986, 24, pp. 231-74.

Johansen, Søren. "Estimation and Hypothesis Testing of Cointegration Vectors in Gaussian Vector Autoregressive Model." Econometrica, November 1991, 59(6), pp. 1551-80.

Jouini, Jamel and Nouira, Leïla. "Mean-Shifts and Long-Memory in the U.S. Ex Post Real Interest Rate." Unpublished manuscript, GREQAM, Université de la Méditerranée, 2006.

Karanasos, M.; Sekioua, S.H. and Zeng, N. "On the Order of Integration of Monthly US Ex-ante and Ex-post Real Interest Rates: New Evidence from Over a Century of Data." Economics Letters, 2006, 90(2), pp. 163-69.

King, Robert G.; Plosser, Charles I.; Stock, James H. and Watson, Mark W. "Stochastic Trend and Economic Fluctuations." American Economic Review, September 1991, 81(4), pp. 819-40.

King, Robert G. and Watson, Mark W. "Testing LongRun Neutrality.” Federal Reserve Bank of Richmond Economic Quarterly, Summer 1997, 83(3), pp. 69-101; www.richmondfed.org/publications/ economic research/economic quarterly/pdfs/ summer1997/king.pdf.

Koopmans, Tjalling C. "On the Concept of Optimal Economic Growth," in The Economic Approach to Development Planning. Amsterdam: Elsevier, 1965, pp. 225-300.

Koustas, Zisimos and Lamarche, Jean-François. "Evidence of Nonlinear Mean Reversion in the Real Interest Rate.” Applied Economics, 2008 (forthcoming).

Koustas, Zisimos and Serletis, Apostolos. "On the Fisher Effect." Journal of Monetary Economics, August 1999, 44(1), pp. 105-30.

Kwiatkowski, Denis; Phillips, Peter C.B.; Schmidt, Peter and Shin, Yongcheol. "Testing the Null Hypothesis of Stationarity Against the Alternative of a Unit Root: How Sure Are We That Economic
Time Series Have a Unit Root?" Journal of Econometrics, 1992, 54(1-3), pp. 159-78.

Lai, Kon S. "Long-Term Persistence in the Real Interest Rate: Evidence of a Fractional Unit Root." International Journal of Finance and Economics, July 1997, 2(3), pp. 225-35.

Lai, Kon S. "On Structural Shifts and Stationarity of the Ex Ante Real Interest Rate." International Review of Economics and Finance, 2004, 13(2), pp. 217-28.

Lai, Kon S. "The Puzzling Unit Root in the Real Interest Rate and Its Inconsistency with Intertemporal Consumption Behavior." Journal of International Money and Finance, February 2008, 27(1), pp. 140-55.

Lioui, Abraham and Poncet, Patrice. "Monetary Non-Neutrality in the Sidrauski Model Under Uncertainty." Economics Letters, July 2008, 100(1), pp. 22-26.

Lucas, Robert E. "Asset Prices in an Exchange Economy.” Econometrica, November 1978, 46(6), pp. 1429-45.

Lütkepohl, Helmut and Saikkonen, Pentti. "Order Selection in Testing for the Cointegrating Rank of a VAR Process," in Robert F. Engle and Halbert White, eds., Cointegration, Causality, and Forecasting. A Festschrift in Honor of Clive W.J. Granger. Oxford: Oxford University Press, 1999, pp. 168-99.

Luukkonen, Ritva; Saikkonen, Pentti and Teräsvirta, Timo. "Testing Linearity Against Smooth Transition Autoregressive Models." Biometrika, September 1988, 75(3), pp. 491-99.

Maki, Daiki. "Nonparametric Cointegration Analysis of the Nominal Interest Rate and Expected Inflation Rate.” Economics Letters, December 2003, 81(3), pp. 349-54.

Meltzer, Allan H. "Origins of the Great Inflation." Federal Reserve Bank of St. Louis Review, March/April 2005, 87(2), pp. 145-75; research.stlouisfed.org/publications/review/05/03/ part2/Meltzer.pdf. 
Mikusheva, Anna. "Uniform Inference in Autoregressive Models." Econometrica, 2007, 75(5), pp. 1411-52.

Million, Nicolas. "Central Bank's Interventions and the Fisher Hypothesis: A Threshold Cointegration Investigation." Economic Modelling, December 2004, 21(6), pp. 1051-64.

Mishkin, Frederic S. "The Real Rate of Interest: An Empirical Investigation." Carnegie-Rochester Conference Series on Public Policy, January 1981, 15, pp. 151-200.

Mishkin, Frederic S. "The Real Interest Rate: A Multi-Country Empirical Study." Canadian Journal of Economics, May 1984, 17(2), pp. 283-311.

Mishkin, Frederic S. "Is the Fisher Effect for Real? A Reexamination of the Relationship Between Inflation and Interest Rates." Journal of Monetary Economics, November 1992, 30(2), pp. 195-215.

Mishkin, Frederic S. and Simon, John. "An Empirical Examination of the Fisher Effect in Australia." Economic Record, September 1995, 71(214), pp. 217-29.

Mundell, Robert. "Inflation and Real Interest." Journal of Political Economy, June 1963, 71(3), pp. 280-83.

Nelson, Charles R. and Schwert, G. William. "ShortTerm Interest Rates as Predictors of Inflation: On Testing the Hypothesis that the Real Interest Rate Is Constant." American Economic Review, June 1997, 67(3), pp. 478-86.

Ng, Serena and Perron, Pierre. "Lag Length Selection and the Construction of Unit Root Tests with Good Size and Power." Econometrica, November 2001, 69(6), pp. 1519-54.

Orphanides, Athanasios and Wilcox, David W. "The Opportunistic Approach to Disinflation." International Finance, Spring 2002, 5(1), pp. 47-71.

Padovano, Fabio and Galli, Emma. "Tax Rates and Economic Growth in the OECD Countries (19501999)." Economic Inquiry, January 2001, 39(1), pp. 44-57.
Peláez, Rolando F. "The Fisher Effect: Reprise.” Journal of Macroeconomics, Spring 1995, 17(2), pp. 333-46.

Perron, Pierre. "The Great Crash, the Oil Price Shock and the Unit Root Hypothesis." Econometrica, November 1989, 57(6), pp. 1361-401.

Perron, Pierre."Non-stationarities and Non-linearities in Canadian Inflation." Economic Behavior and Policy Choice Under Price Stability. Ottawa: Bank of Canada, 1994, pp. 235-91.

Perron, Pierre and Ng, Serena. "Useful Modifications to Some Unit Root Tests with Dependent Errors and Their Local Asymptotic Properties." Review of Economic Studies, July 1996, 63(3), pp. 435-63.

Perron, Pierre and Rodriguez, Gabriel H. "Residual Based Tests for Cointegration with GLS Detrended Data." Unpublished manuscript, Boston University, 2001.

Perron, Pierre and Vogelsang, Timothy J. "Nonstationarity and Level Shifts with an Application to Purchasing Power Parity." Journal of Business and Economic Statistics, July 1992, 10(3), pp. 301-20.

Pesavento, Elena. "Analytical Evaluation of the Power of Tests for the Absence of Cointegration." Journal of Econometrics, October 2004, 122(2), pp. 349-84.

Phillips, Peter C.B. and Hansen, Bruce E. "Statistical Inference in Instrumental Variables Regression with I(1) Variables." Review of Economic Studies, January 1990, 57(1), pp. 99-125.

Phillips, Peter C.B. and Perron, Pierre. "Testing for a Unit Root in Time Series Regression.” Biometrika, June 1988, 75(2), pp. 335-46.

Pipatchaipoom, Onsurang and Smallwood, Aaron. "Persistence in the Real Interest Rate and the Effects of Calculating Expected Inflation." Unpublished manuscript, University of TexasArlington, 2008. 


\section{Neely and Rapach}

Ramey, Valerie A. "Identifying Government Spending Shocks: It's All in the Timing." Unpublished manuscript, University of California-San Diego, 2008.

Rapach, David E. "International Evidence on the Long-Run Impact of Inflation." Journal of Money, Credit, and Banking, February 2003, 35(1), pp. 23-48.

Rapach, David E. and Weber, Christian E. "Are Real Interest Rates Really Nonstationary? New Evidence from Tests with Good Size and Power." Journal of Macroeconomics, September 2004, 26(3), pp. 409-30.

Rapach, David E. and Wohar, Mark E. "The Persistence in International Real Interest Rates." International Journal of Finance and Economics, 2004, 9(4), pp. 339-46.

Rapach, David E. and Wohar, Mark E. "Regime Changes in International Real Interest Rates: Are They a Monetary Phenomenon?" Journal of Money, Credit, and Banking, October 2005, 37(5), pp. 887-906.

Reis, Ricardo. "The Analytics of Monetary NonNeutrality in the Sidrauski Model." Economics Letters, January 2007, 94(1), pp. 129-35.

Romano, Joseph P. and Wolf, Michael. "Subsampling Intervals in Autoregressive Models with Linear Time Trends." Econometrica, September 2001, 69(5), pp. 1283-314.

Romer, Christina D. "Origins of the Great Inflation: Commentary." Federal Reserve Bank of St. Louis Review, March/April 2005, 87(2 Part 2), pp. 177-85; research.stlouisfed.org/publications/review/05/03/ part2/Romer.pdf.

Romer, Christina D. and Romer, David H. "A New Measure of Monetary Shocks: Derivation and Implications." American Economic Review, September 2004, 94(4), pp. 1055-84.

Romer, Christina D. and Romer, David H. "The Macroeconomic Effects of Tax Changes: Estimates Based on a New Measure of Fiscal Shocks.” NBER Working Paper 12364, National Bureau of Economic Research, 2007; www.nber.org/papers/w13264.pdf.
Romer, David H. Advanced Macroeconomics. Third Edition. New York: McGraw-Hill, 2006.

Rose, Andrew K. "Is the Real Interest Rate Stable?" Journal of Finance, December 1988, 43(5), pp. 1095-112.

Said, Said E. and Dickey, David A. "Testing for Unit Roots in Autoregressive-Moving Average Models of Unknown Order.” Biometrika, December 1984, 71(3), pp. 599-607.

Saikkonen, Pentti. "Asymptotically Efficient Estimation of Cointegrating Regressions." Econometric Theory, March 1991, 7(1), pp. 1-21.

Saikkonen, Pentti and Choi, In. "Cointegrating Smooth Transition Regressions." Econometric Theory, February 2004, 20(2), pp. 301-40.

Samuelson, Paul A. "An Exact Consumption-Loan Model of Interest with or without the Social Contrivance of Money." Journal of Political Economy, December 1958, 66(6), pp. 467-82.

Sarno, Lucio and Taylor, Mark P. "Purchasing Power Parity and the Real Exchange Rate.” International Monetary Fund Staff Papers, March 2002, 49(1), pp. 65-105.

Schwert, G. William. "Effects of Model Specification on Tests for Unit Roots in Macroeconomic Data." Journal of Monetary Economics, July 1987, 20(1), pp. 73-103.

Schwert, G. William. "Testing for Unit Roots: A Monte Carlo Investigation." Journal of Business and Economic Statistics, January 1989, 7(2), pp. 147-59.

Shapiro, Matthew D. and Watson, Joel. "Sources of Business Cycle Fluctuations,” in Stanley Fischer, ed., NBER Macroeconomics Annual 1988. Cambridge, MA: The MIT Press, 1988, pp. 11-48.

Shimotsu, Katsumi. "Exact Local Whittle Estimation of Fractional Integration with an Unknown Mean and Time Trend.” Working paper, Queen's University, 2008. 
Shimotsu, Katsumi and Phillips, Peter C.B. "Exact Local Whittle Estimation of Fractional Integration." Annals of Statistics, August 2005, 33(4), pp. 1890-933.

Stock, James H. and Watson, Mark W. "A Simple Estimator of Cointegrating Vectors in Higher Order Integrated Systems.” Econometrica, July 1993, 61(4), pp. 782-820.

Stock, James H. and Watson, Mark W. "Forecasting Inflation.” Journal of Monetary Economics, October 1999, 44(2), pp. 293-335.

Stock, James H. and Watson, Mark W. "Forecasting Output and Inflation: The Role of Asset Prices." Journal of Economic Literature, September 2003, 41(3), pp. 788-829.

Stock, James H. and Watson, Mark W. "Why Has U.S. Inflation Become Harder to Forecast?" Journal of Money, Credit, and Banking, October 2007, 39(1), pp. 3-33.

Summers, Lawrence H. "The Non-Adjustment of Nominal Interest Rates: A Study of the Fisher Effect," in James Tobin, ed., Symposium in Honor of Arthur Okun. Washington, DC: Brookings Institute, 1983, pp. 201-41.
Sun, Yixiao and Phillips, Peter C.B. "Understanding the Fisher Equation." Journal of Applied Econometrics, November-December 2004, 19(7), pp. 869-86.

Taylor, John B. "Discretion versus Policy Rules in Practice." Carnegie-Rochester Conference Series on Public Policy, December 1993, 39, pp. 195-214.

Tobin, James. "Money and Economic Growth." Econometrica, October 1965, 33(4), pp. 671-84.

Tsay, Wen-Jen. "Long Memory Story of the Real Interest Rate." Economics Letters, June 2000, 67(3), pp. 325-30.

Wallace, Myles S. and Warner, John T. "The Fisher Effect and the Term Structure of Interest Rates: Tests of Cointegration." Review of Economics and Statistics, May 1993, 75(2), pp. 320-24.

Weiss, Laurence M. "The Effects of Money Supply on Economic Welfare in the Steady State." Econometrica, April 1980, 48(3), pp. 565-76. 


\section{APPENDIX}

\section{Unit Root and Cointegration Tests}

This appendix briefly describes the basic framework for unit root and cointegration testing; Hamilton (1994) details the subject. Following Dickey and Fuller (1979) and Said and Dickey (1984), unit root tests are typically based on the autoregressive (AR) representation of a time series, which can be written as follows:

$$
y_{t}-\mu=\rho_{1}\left(y_{t-1}-\mu\right)+\ldots+\rho_{k}\left(y_{t-k}-\mu\right)+e_{t},
$$

where $e_{t}$ is a white noise disturbance term. When the sum of the AR coefficients in equation (A1),

$$
\rho=\sum_{j=1}^{k} \rho_{j}
$$

equals 1 , shocks to $y_{t}$ persist forever- $y_{t}$ has a unit root and thus has no tendency to revert to an unconditional mean. Testing the null hypothesis that $y_{t} \sim I(1)$ against the alternative hypothesis that $y_{t} \sim I(0)$ is equivalent to testing

$$
\sum_{j=1}^{k} \rho_{j}=1 \text { versus } \sum_{j=1}^{k} \rho_{j}<1 \text {. }
$$

Researchers usually ignore the possibility that $\rho>1$, since this would imply an explosive process, which we do not observe in the data. The $t$ statistic on $\gamma$ in the following augmented Dickey-Fuller (ADF) regression provides a convenient test statistic for the unit root null hypothesis:

$$
\Delta y_{t}=\delta+\gamma y_{t-1}+\tilde{\rho}_{1} \Delta y_{t-1}+\ldots+\tilde{\rho}_{k-1} \Delta y_{t-(k-1)}+e_{t},
$$

where $\delta=\mu(1-\rho), \gamma=-(1-\rho)$, and

$$
\tilde{\rho}_{i}=-\sum_{j=i+1}^{k} \rho_{j} \cdot 25
$$

Under the null hypothesis that $y_{t} \sim I(1), \gamma=0$, while $\gamma<0$ under the alternative hypothesis that $y_{t} \sim I(0)$. The $t$ statistic on $\gamma$ in equation (A2) has a nonstandard distribution, necessitating simulation methods to obtain critical values.

Cointegration tests are closely related to unit root tests in that they ask whether any linear combination of some set of $I(1)$ processes (say, $y_{t}$ and $x_{t}$ ) are stationary or cointegrated. The popular, residualbased augmented Engle and Granger (1987, AEG) procedure uses the following ordinary least squares (OLS) regression as a first step in testing the null hypothesis of no cointegration:

$$
y_{t}=\theta_{0}+\theta_{1} x_{t}+u_{t}
$$

The cointegrating vector, which defines the stable long-run relationship between $y_{t}$ and $x_{t}$ (if it exists), is given by $\left(1,-\theta_{1}\right)^{\prime}$. One then runs an ADF-type unit root test-with no constant-on the regression residuals, $\hat{u}_{t}=y_{t}-\left(\hat{\theta}_{0}+\hat{\theta}_{1} x_{t}\right)$, where $\hat{\theta}_{0}$ and $\hat{\theta}_{1}$ are the OLS estimates of $\theta_{0}$ and $\theta_{1}$. The AEG test statisticthe ADF test statistic from the residual regression-also has a nonstandard asymptotic distribution, which requires simulated critical values. When $y_{t}$ and $x_{t}$ are cointegrated, $\hat{\theta}_{0}$ and $\hat{\theta}_{1}$ are superconsistent, converging to their probability limits faster than the usual rate of

$$
1 / \sqrt{T} \text {. }
$$

\footnotetext{
${ }^{25}$ The unit root tests developed by Phillips and Perron (1988) are closely related to ADF tests and are frequently used in the literature. We refer
} to both ADF and Phillips and Perron (1988) tests simply as ADF tests in our discussion of the empirical literature in the text. 
Endogeneity bias, however, renders conventional OLS standard errors incorrect. When $y_{t}$ and $x_{t}$ are cointegrated, fully modified OLS (FM-OLS; Phillips and Hansen, 1990) and dynamic OLS (DOLS; Saikkonen, 1991; Stock and Watson, 1993) procedures efficiently estimate $\theta_{0}$ and $\theta_{1}$ with appropriate standard errors.

Johansen (1991) develops a cointegration test procedure based on the likelihood function of a system of equations that simultaneously tests the null hypothesis of no cointegration and consistently and efficiently estimates the cointegrating vector (if it exists). This system-based approach is also popular in applied research and is potentially more powerful than the single-equation-based AEG approach (Pesavento, 2004).

Unit root and cointegration tests have two significant problems. First, they have low power to reject the null if the true model is a highly persistent but stationary process (DeJong et al., 1992). Second, moving-average components in the underlying data-generating process complicate inference from unit root and cointegration tests. Schwert $(1987,1989)$ shows that ADF unit root tests can have substantial size distortions that lead to spurious rejections of the unit root null hypothesis in the presence of a significant moving-average component. ${ }^{26}$ Lütkepohl and Saikkonen (1999) show that such size distortions can also affect cointegration tests. This is potentially relevant when analyzing the EPRR, as Perron and $\mathrm{Ng}$ (1996) and others show that inflation rates often have sizable moving-average components. ${ }^{27}$

${ }^{26}$ There are two strategies for dealing with a significant moving-average component in the data-generating process when performing ADF unit root tests: (i) include a large number of lags when estimating (A2), as an autoregressive moving average process with finite-order lag polynomials can be expressed as an infinite-order AR process; (ii) include the moving-average component in the data generating process when simulating critical values.

${ }^{27}$ Perron (1994) observes that the inflation rate could exhibit a substantial moving-average component if the monetary authority offsets inflationary or disinflationary shocks away from a target price level path. 
